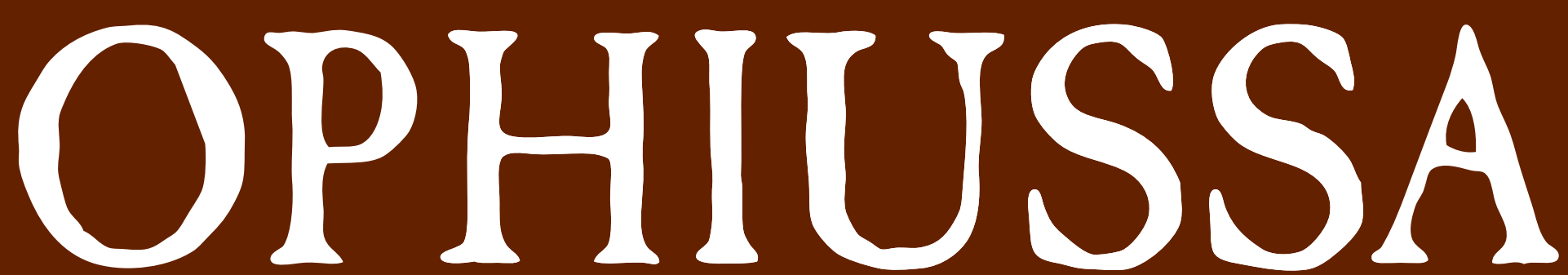
REVISTA DO CENTRO DE ARQUEOLOGIA DA UNIVERSIDADE DE LISBOA

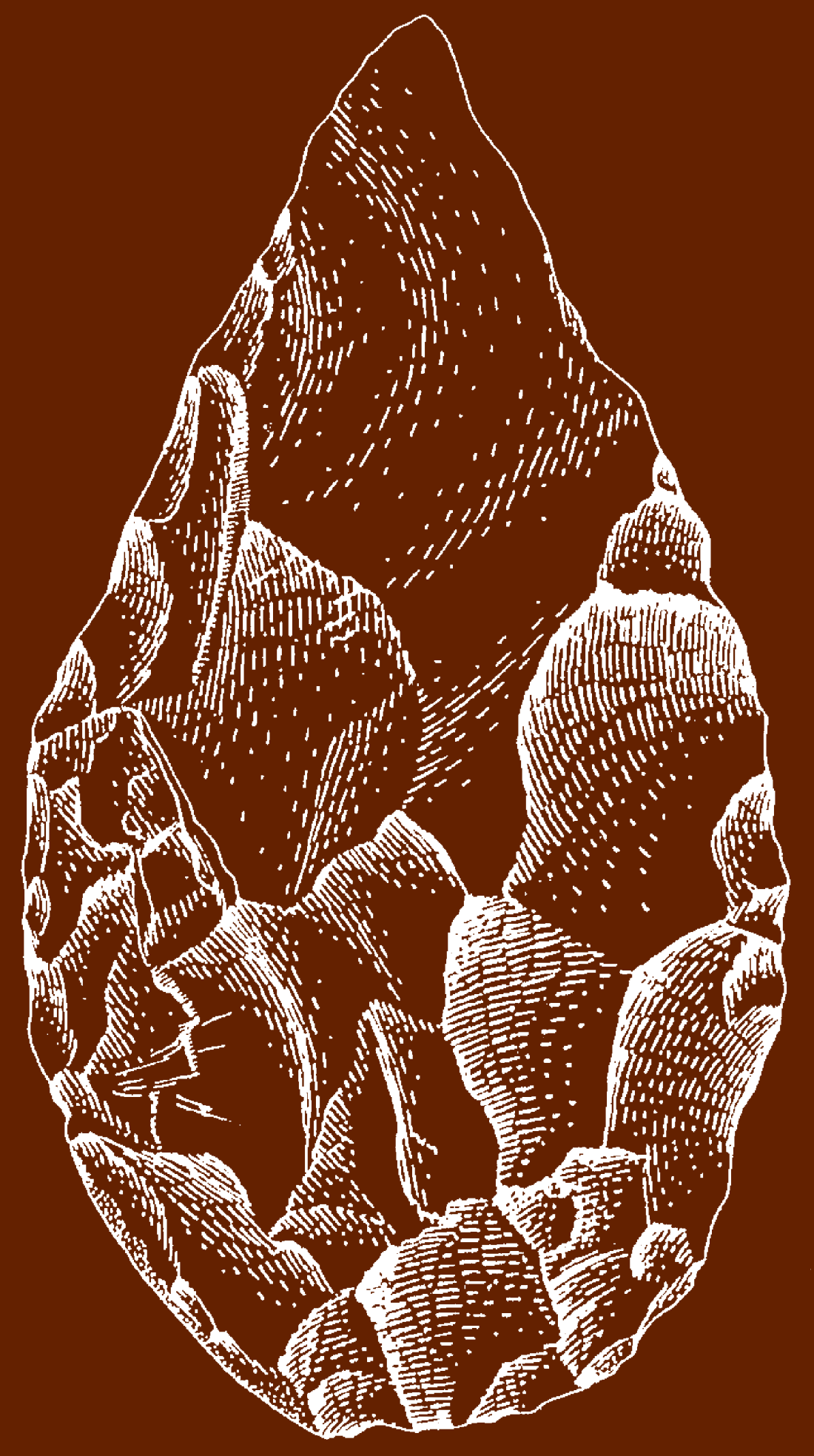

CENTRO DE ARQUEOLOGIA

DA UNIVERSIDADE

DE LISBOA 


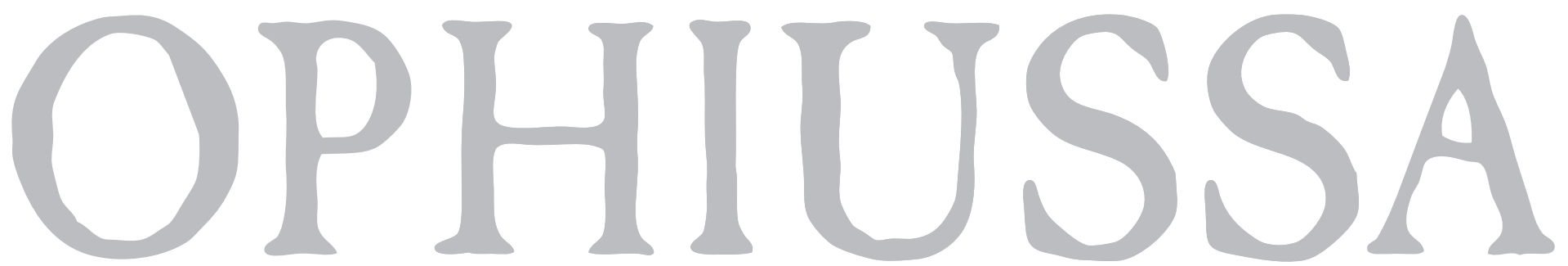

REVISTA DO CENTRO DE ARQUEOLOGIA DA UNIVERSIDADE DE LISBOA

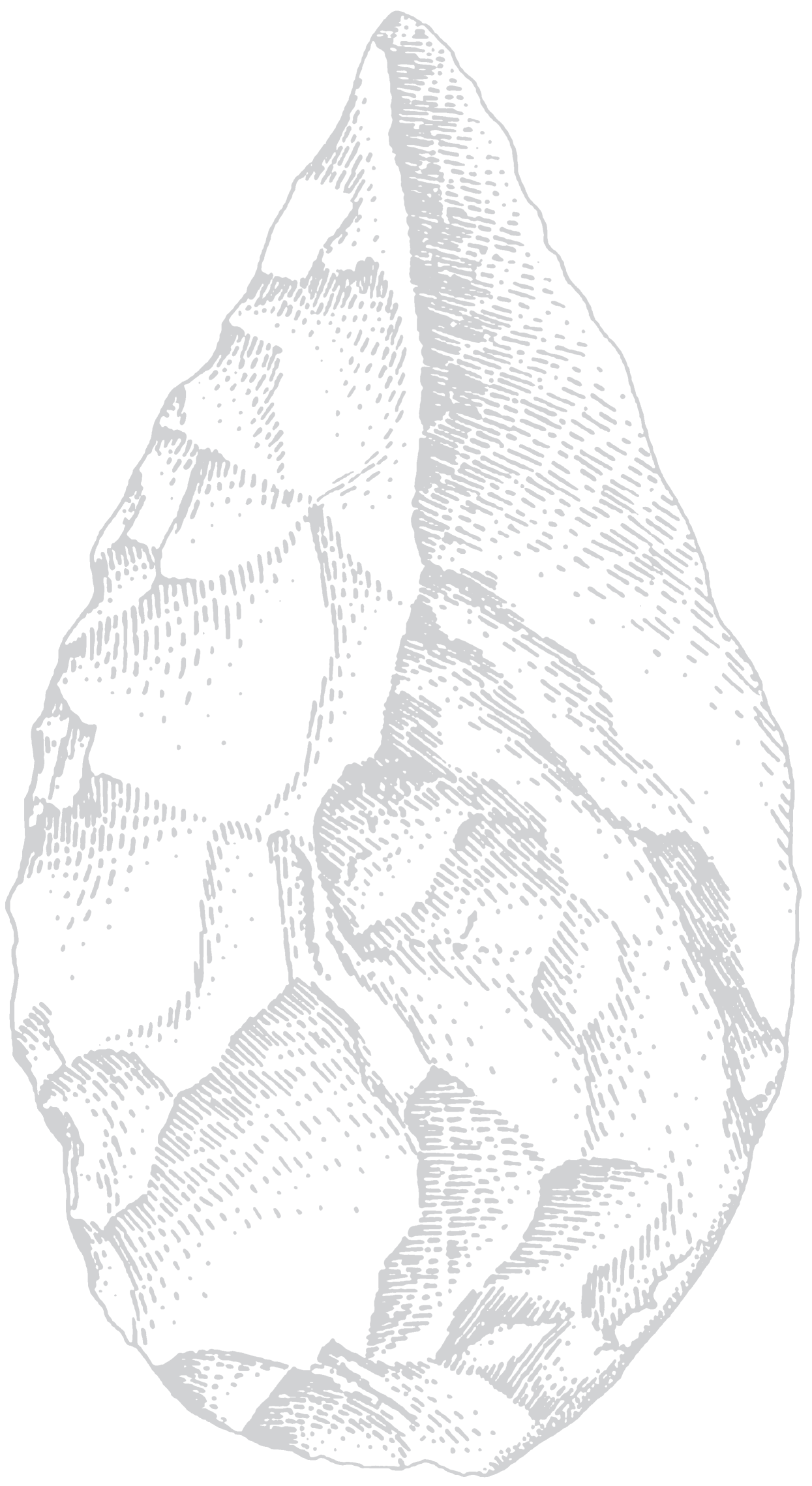




\section{U IISBOA \\ UNIVERSIDADE

\section{OPHIUSSA REVISTA DO CENTRO DE ARQUEOLOGIA DA UNIVERSIDADE DE LISBOA}

PUBLICAÇÃO ANUAL · ISSN 1645-653X · E-ISSN 2184-173X

Volume 5 - 2021

DIRECÇÃO E COORDENAÇÃO EDITORIAL

Ana Catarina Sousa

Elisa Sousa

\section{CONSELHO CIENTÍFICO}

André Teixeira

UNIVERSIDADE NOVA DE LISBOA

\section{Carlos Fabião}

UNIVERSIDADE DE LISBOA

Catarina Viegas

UNIVERSIDADE DE LISBOA

\section{Gloria Mora}

UNIVERSIDAD AUTÓNOMA DE MADRID

\section{Grégor Marchand}

CENTRE NATIONAL DE LA RECHERCHE SCIENTIFIQUE

\section{João Pedro Bernardes}

UNIVERSIDADE DO ALGARVE

José Remesal

UNIVERSIDADE DE BARCELONA

Leonor Rocha

UNIVERSIDADE DE ÉVORA

Manuela Martins

UNIVERSIDADE DO MINHO

Maria Barroso Gonçalves

INSTITUTO SUPERIOR DE CIÊNCIAS DO TRABALHO E DA EMPRESA

\section{Mariana Diniz}

UNIVERSIDADE DE LISBOA

Raquel Vilaça

UNIVERSIDADE DE COIMBRA

Victor S. Gonçalves

UNIVERSIDADE DE LISBOA

Xavier Terradas Battle

CONSEJO SUPERIOR DE INVESTIGACIONES CIENTÍFICAS

\section{SECRETARIADO}

André Pereira

\section{CAPA}

Biface proveniente de Casal do Azemél (Leiria).

Desenho de Amélia Marques. Museu D. Diogo de Sousa

(MDDS). (Cunha-Ribeiro, 1999)
REVISOR DE ESTILO

Francisco B. Gomes

PAGINAÇÃO

TVM Designers

IMPRESSÃO

AGIR - Produções Gráficas

DATA DE IMPRESSÃO

Dezembro de 2021

EDIÇÃO IMPRESSA (PRETO E BRANCO)

300 exemplares

EDIÇÃO DIGITAL (A CORES)

www.ophiussa.letras.ulisboa.pt

ISSN 1645-653X / E-ISSN 2184-173X

DEPÓSITO LEGAL 190404/03

Copyright ( $) 2021$, os autores

EDIÇÃO

UNIARQ - Centro de Arqueologia

da Universidade de Lisboa,

Faculdade de Letras de Lisboa

1600-214 Lisboa.

www.uniarq.net

www.ophiussa.letras.ulisboa.pt

uniarq@letras.ulisboa.pt

Revista fundada por Victor S. Gonçalves (1996). O cumprimento do acordo ortográfico de 1990 foi opção de cada autor.

Esta publicação é financiada por fundos nacionais através da FCT - Fundação para a Ciência e a Tecnologia, I.P., no âmbito dos projectos UIDB/00698/2020 e UIDP/00698/2020. 
ÍNDICE

O tecno-complexo Acheulense em Portugal:

contribuição para um balanço dos conhecimentos

CARLOS FERREIRA, JOÃO PEDRO CUNHA-RIBEIRO, EDUARDO MÉNDEZ-QUINTAS

Brief overview of zooarchaeological research within the framework

of Middle Palaeolithic subsistence theories

MARIANA NABAIS

A distribuição espacial dos materiais líticos da UE003 do Rodo:

testemunho de reocupações do sítio ao longo do Tardiglaciar?

CRISTINA GAMEIRO, THIERRY AUBRY, BÁRBARA COSTA, SÉRGIO GOMES,

YANN LE JEUNE, CARMEN MANZANO, MAURIZIO ZAMBALDI

O sítio do Neolítico Antigo de Montum de Baixo (Melides - Alentejo Litoral)

JOAQUINA SOARES, CARLOS TAVARES DA SILVA, SUSANA DUARTE

A economia alimentar em Chibanes (Setúbal) - horizonte campaniforme

JOÃO LUÍS CARDOSO, CARLOS TAVARES DA SILVA, JOAQUINA SOARES, FILIPE MARTINS

Luto en la cara: ablaciones de duelo en el Mediterráneo Ancestral

ÁLVARO GÓMEZ PEÑA, JOSÉ LUIS ESCACENA CARRASCO

Dois conjuntos anfóricos do Castelo de São Jorge (Lisboa):

Largo de Santa Cruz do Castelo e Pátio José Pedreira

VICTOR FILIPE

A face romana de Santa Olaia (Figueira da Foz, Portugal) -

uma leitura possível a partir da cultura material

RICARDO COSTEIRA DA SILVA, SARA OLIVEIRA ALMEIDA, ISABEL PEREIRA

Cerâmica estampada britânica em Portugal (1780-1920).

Identidade, domesticidade e relações

TÂNIA CASIMIRO, INÊS CASTRO, TIAGO SILVA

Recensões bibliográficas

(TEXTOS: JOÃO LUÍS CARDOSO, ANA CATARINA SOUSA, VICTOR S. GONÇALVES,

FRANCISCO B. GOMES, PEDRO ALBUQUERQUE, LEYRE MORGADO-RONCAL)

Política editorial 


\title{
Brief overview of zooarchaeological research within the framework of Middle Palaeolithic subsistence theories
}

\author{
Revisão sumária do percurso de investigação \\ zooarqueológica no quadro teórico dos estudos \\ de subsistência do Paleolítico Médio
}

\author{
MARIANA NABAIS \\ Institute of Archaeology, University College London \\ UNIARQ - Centro de Arqueologia da Universidade de Lisboa \\ mariananabais@gmail.com \\ ORCID iD: https://orcid.org/0000-0001-5344-237X
}

\begin{abstract}
In the course of a general review of zooarchaeological studies, particular attention is given to the development of the thinking process associated with hominin dietary strategies. Since the dawn of archaeological studies animal bones were noticed and recovered in association with man-made tools. Since then, faunal remains have been discussed as the result of human dietary practices. However, the way such feeding activities were conducted has been the focus of an ongoing heated debate. Different subsistence strategies - i.e. Hunting vs Scavenging; Specialization vs Broad Spectrum; Inland vs Coastal Adaptation - have a strong impact on the image we create about our ancestors. Indeed, depending on the mode of acquisition and processing of faunal remains, hominins have been assessed on their cognitive abilities and, therefore, stamped as more, or less, evolved. More recently, new insights have been provided by the development of actualistic studies, highlighting the need to understand in detail the origin of the faunal accumulations. The formation of faunal assemblages in archaeological sites is not only dependent on anthropogenic activities. A myriad of other agents - ranging from natural events to a variety of mammal and bird predators - can also be responsible, or to provide strong inputs, to the formation of faunal accumulations. Therefore, it is imperative to first put faunal assemblages into a site-specific context, making use of a detailed taphonomic methodology, before conducting any kind of analysis and consequent interpretations.
\end{abstract}

KEY WORDS: Archaeological thought; Historiography; Zooarchaeology; Neanderthal; Taphonomy.

RESUMO: Durante uma revisão geral da evolução do pensamento zooarqueológico, é dada especial atenção ao desenvolvimento do processo intelectual associado às estratégias de subsistência dos hominídeos. Desde os primórdios da prática arqueológica que os ossos de animais foram observados e recuperados em contexto de escavação e em associação com outros utensílios de origem antrópica. Os restos de fauna têm, desde então, sido apresentados como o resultado de práticas alimentares humanas. Contudo, o modo como tais actividades foram realizadas no passado tem sido o centro de um contínuo e aceso debate. Diferentes estratégias de subsistência - como Caça vs Necrofagia; Dieta Especializada vs Dieta de Largo Espectro; Adaptação ao Interior vs Adaptação Costeira - têm tido um forte impacto na imagem que criamos sobre 
os nossos antepassados. O modo de aquisição e processamento de elementos faunísticos influenciam a forma como entendemos as suas capacidades cognitivas e, consequentemente, a forma como os consideramos mais, ou menos, evoluídos. Mais recentemente, novos dados têm vindo a ser fornecidos por variados estudos actualísticos que sublinham a necessidade de compreender de forma pormenorizada a origem das acumulações faunísticas. A formação destes conjuntos em contexto arqueológico não está apenas dependente de actividades antropogénicas. Uma pluralidade de outros agentes poderá também originar estas acumulações, ou contribuir significativamente para a sua formação, tais como eventos naturais ou a actividade de uma grande variedade de aves e mamíferos predadores. Assim sendo, torna-se imperativo que se proceda a uma contextualização do sítio arqueológico através de estudos tafonómicos detalhados antes da análise, e consequente interpretação, destes conjuntos faunísticos.

PALAVRAS-CHAVE: Pensamento arqueológico; Historiografia; Zooarqueologia; Neandertal; Tafonomia.

\section{HOMININ LARGE GAME CONSUMPTION}

Since the late $19^{\text {th }}$ century the association of lithic tools and faunal remains in archaeological sites has been considered to reflect hominin subsistence behaviour, implying hunting and carcass-processing activities (Domínguez-Rodrigo 2002). According to Darwin (1871), such accomplishments - together with bipedalism and the abandonment of life in the trees were indicative of a certain stage of hominization that separated humans from other apes. Further evidence of such humanized behaviours was later given by authors like Dart (1959), who argued for the primacy of meat-eating by early humans in many African sites. Such ideas were widespread, leading to the general acceptance of hunting as the main hominin subsistence strategy, which was later termed the Hunting Hypothesis (Domínguez-Rodrigo 2002; Stanford 1999).

The Hunting Hypothesis was well-received and popular among academics during the first part of the $20^{\text {th }}$ century, reaching its peak with the Man the Hunter conference held in Chicago in 1966, where several ethnographic studies of recent hunting and gathering communities were presented (Lee - DeVore 1968). Hunting was perceived as the most efficient method to adapt to a myriad of environments, since the targeting of substantial herds of large herbivores guaranteed the sustenance of hunter-gatherer groups (Hart Sussman 2005; Stanford 1999). However, in the 1970s, Glyn Isaac and colleagues (Isaac 1978; 1982; Isaac - Crader 1981) changed the focus from the hunting process per se to the hominin social cooperation that was seen as the real trait of progress and evolution.
The Home Base / Food Sharing Hypothesis argued that food resources other than meat were part of the diet, with women being generally responsible for procurement of plant foods whilst men were accountable for hunting activities. Furthermore, Isaac tackled issues like the role of non-anthropogenic factors (e.g. rivers, other carnivores) in the accumulation of archaeological material (Isaac 1983).

Such taphonomic concerns were extensively explored during the 1970s and 1980s within the frame of the New Archaeology, when several actualistic and experimental studies were conducted. This approach resulted in works highlighting the importance of non-cultural agents in the formation of archaeological assemblages. Amongst the most notable works is the one of Brain (1981), who demonstrated through detailed taphonomic analysis that the bone deposits interpreted by Dart (1959) as resulting from hominin hunting activities were, instead, due to predator-scavenger activities, and that humans were among the species preyed upon. Similarly, Binford's ethnographic work among the Nunamiut (Binford 1978) attempted to reconstruct the different agents and activities involved in the formation of bone accumulations through the body part representation patterns found in faunal assemblages. Binford compared modern hunter-gatherer and predator-scavenger assemblages with archaeological collections, concluding that several Lower Palaeolithic bone accumulations (e.g. in Olduvai Gorge Beds I and II, Swanscombe, Torralba and Klasies River Mouth) were in fact the result of carnivore kills with subsequent hominin scavenging intervention (Binford 1981; 1984; 1985; 1987). This resulted in 
a dramatic shift in the interpretation of hominin subsistence behaviour with some authors rejecting early hominins as big game hunters (e.g. Binford 1981; 1985; Blumenschine 1986; 1992; Selvaggio 1998a; 1998b), but seeing them as purely scavengers relying on the carcasses from other carnivore kills in order to survive. Furthermore, Binford considered that hunting was only possible among Anatomical Modern Humans, an idea also shared at the time by researchers like Mellars and Stringer (1989) who considered that pre-modern humans lacked the physical, behavioural and technological ability for large game hunting.

In the 1990s, the gap between such opposing ideas - i.e. whether hominins were hunters or scavengers started to narrow down. Some authors placed hominins back in their faunal community context (e.g. Stiner 1994), and included them in the wider carnivore guild (Stiner 2002) in order to better understand the interaction and competition of humans and other species for the resources available. Such approach has been producing evidence supporting both hunting and scavenging behaviours (Gaudzinski 1996). Moreover, zooarchaeological studies from several European Middle Palaeolithic sites have been advocating different, and frequently competing, Neanderthal subsistence behaviours. Specialised monospecific hunting of large and medium-sized game has been proposed for sites where a limited number of species is recorded, mainly focusing on herbivores like large bovids, horses and reindeer. Examples of such monospecific subsistence are found in sites like Wallertheim (Germany) (Gaudzinski 1996), Schöeningen (Germany) (Gaudzinski-Windheuser Niven 2009), Mauran (France) (Farizy - David - Jaubert 1994) or La Borde (France) (Jaubert et al. 1990). Other sites demonstrate the exploitation of megafaunal species like the proboscideans from the Spanish sites of Torralba and Ambrona (Villa 1990; Villa et al. 2005) and Preresa (Yravedra et al. 2012), or the mammoths and woolly rhinoceros from La Cotte de St Brelade (Jersey) (Scott 1980; 1986; Smith 2015), and the Belgian sites of Goyet (Wißing et al. 2016) or Spy Cave (Weyrich et al. 2017), among others. Current archaeological evidence suggests that Neanderthals were successful hunters of large ungulates (e.g. Discamps - Jauber - Bachellerie 2011; Gaudzinski-Windheuser - Kindler 2012; Kindler - Smith - Wagner 2014; Rendu 2010). However, there is still some scepticism as to whether Neanderthals specifically targeted megafauna and large ungulates, or if they simply scavenged from other carnivore kills or natural deaths (e.g. Burke 2004; Mellars 1996; Stiner 1994). Nonetheless, it is difficult to argue against the fact that scavenging hominins had to compete and fight over carcasses with other carnivores (Gaudzinski 2004).

Despite the manner of meat acquisition, Neanderthal consumption of large game has been widely accepted, and isotope analysis has been crucial in perpetuating such views (e.g. Wißing et al. 2016). The first carbon and nitrogen analyses carried out in the 1990s revealed Neanderthals as top meat consumers, clustering close to wolves and hyenas (Bocherens et al. 1991). However, and as later noted by Bocherens (2009), sample size was small (with only six samples fulfilling the necessary analysis criteria). Moreover, all samples were recovered from Neanderthal occupations relating to cold periods and to northern latitudes, with clear lack of evidence from sites in more southern positions (Hardy 2010). Nonetheless, isotope analyses made by Salazar-García et al. (2013) in Mediterranean sites showed similar results to those from cold environments, implying a predominant consumption of terrestrial resources. Ecker et al. (2013) support such conclusions through carbon and oxygen isotope analyses on Neanderthal tooth enamel samples from southern France, demonstrating a preference for large herbivore consumption.

However, the growing body of vegetal evidence has shown the inclusion of plant foods in pre-sapiens diets (Hardy - Moncel 2011; Hardy et al. 2012; 2013: 2016; Henry - Brooks - Piperno 2011; 2014; Weyrich et al. 2017). Nutshells from stone pine (Pinus pinea) were found in Gorham's Cave (Gibraltar) (Ward - Gale - Carruthers 2012), Gruta da Figueira Brava (Portugal) (Zilhão et al. 2020), and there is further evidence of consumption of pine nuts, moss and mushroom from Neanderthal teeth from El Sidrón Cave (Spain) (Weyrich et al. 2017). Other low ranked plants, like starches and grass seeds, were also consumed in several European Neanderthal sites (Henry - Brooks - Piperino 2014), and in the Near East such as Shanidar Cave (Iraq) (Henry - Brooks - Piperino 2011). In addition, there is rising evidence for the exploitation and consumption of small game and marine resources in the Middle Palaeolithic (e.g. Barton et al. 1999; Blasco - Fernández-Peris 2012a; 2012b; Blasco et al. 2016; Stiner 1994; 
2005; Stringer et al. 2008; Zilhão et al. 2010; 2020);. Such research advances are therefore changing the traditional palaeodiet perceptions based exclusively on large game consumption and, instead, are becoming significantly more complex.

\section{HOMININ BROAD DIETS}

Formulations of broad spectrum diet theories had their origin in research related with food production and the dawn of domestication. In a well-known 1968 paper, Lewis Binford criticises Braidwood's nuclear zones theory (Braidwood 1960; 1963), which stated that food production was not an anthropogenic response to climate change but resulted from an increased cultural awareness of the environment, its resources and how to manipulate them. It was only in the terminal Pleistocene that hunter-gatherers had developed such a deep understanding of the flora and fauna of their living environments, with the direct consequence of domestication. Nevertheless, according to Binford (1968: 323), such cultural decision-making could not be confirmed, and it was impossible to test. Moreover, he argued that it was unlikely that prehistoric hunter-gatherer populations would change their long-term subsistence strategies unless there was considerable disequilibrium resulting from changes in the environment, forcing human groups to adapt to a new reality. Binford illustrated his theory by comparing the distribution of Mesolithic and Neolithic sites, which he argued was determined by environmental factors. Rising sea levels and other changes forced people to find new subsistence strategies, like heavy consumption of marine resources and the beginning of food production.

Binford's density disequilibrium model considered demographic increase as a possibility for hominin widening diets, but only in marginal areas and in very specific conditions. In most cases, population increase would only encourage "a regressive change in which a less complex cultural form is adapted" (Binford 1968: 331). Conversely, Flannery (1969) presented demographic expansion as a critical factor. Although the importance of climate change was not ignored, he did not consider environment as the main engine to changes in subsistence patterns. Instead, broader diets were triggered by population pressure and disequilibrium towards resource carrying capacity, which forced mid-Upper Palaeolithic groups to use smaller size resources, more reliable and predictable in certain seasons of the year, like "fish, crabs, water turtles, molluscs, land snails, partridges and migratory water fowl" (Flannery 1969: 77). The increasingly broad spectrum exploitation from 20,000 years $B C$ to about 6,000 BC was thus responsible for a change in mental attitudes, which started considering any resource as potential food. Flannery then argued that only after these developments would the first domestication be possible (Flannery 1969). Although such small resources would not be a substitute for specialised ungulate hunting, most of them could be storable, some were high in calories (like acorn and pistachio), and others provided important nutrients, like calcium from land snails, or vitamin A from mussels. Also, invertebrates and vegetal foods could easily be collected by women and children, which would complement men's ungulate hunting (Flannery 1969).

With Malthusianism theories widely accepted, Flannery's Broad Spectrum Revolution was well received. Further support came from Mark Cohen's The Food Crisis in Prehistory (Cohen 1977) stating in favour of population pressure. Cohen also stressed that changes in the diet would impact on procurement efficiency. Therefore, smaller, lower energy and more labour-intensive resources would integrate the new diet patterns with the direct consequence of a significant increase in energy costs. As is well summarised by Christenson (1980: 36), the first consequence of population growth would be the intensification and specialisation of the high potential resources already explored. Once these started to decline, then diet diversification would occur incorporating animals giving less energy but with less cost input. However, overexploitation of these low rank resources would eventually occur and other low ranked foods, which are more labour intensive, would have to be included in the diets. These two types of low rank resources - with less and more cost input - were later zooarchaeologically defined by Mary Stiner and colleagues (Stiner et al. 1999; Stiner - Munro - Surovell 2000) as small slow prey (i.e. tortoises, shellfish) and small fast prey (i.e. lagomorphs, birds), respectively.

Archaeological evidence was soon provided by Clark and Straus (1986), who presented the Upper 
Palaeolithic site of La Riera (Cantabria, Spain) as the perfect example of resource intensification, specialisation and diversification. They started by rejecting any significant environmental change during the cave's occupation and showing a progressive specialisation on red deer consumption through catastrophic mortality profiles suggesting herd hunting. Further intensification was noted through red deer bone breakage patterns that, at a certain stage in the stratigraphic sequence, started showing heavy exploitation of marrow and grease. Such intensification was supported by significant increase in new-born individuals, which was interpreted as a clear sign of red deer overexploitation. Concurrently, limpet shells were intensively consumed resulting in a size decline, indicating overexploitation. In addition, resource diversity was attested by an increase in the range of molluscs from different environments and the inclusion of marine species not previously exploited, like fish and sea urchins.

In the 1980s, archaeologists and anthropologists found support for their energy cost efficiency models in Behavioural Ecology and its Optimal Foraging Theory. The latter assumes that resources are selected so as to maximise the effort spent in collecting or hunting them. The ultimate goal is to define prey choice models in order to understand the rules used by foragers to enhance the efficiency of their resource selection (Zeder 2012 and references therein). Optimal Foraging Theory was embraced by the zooarchaeological community with a spotlight on the work of Mary Stiner and colleagues (Stiner 2001; Stiner - Munro 2002; Stiner - Munro - Surovell 2000). They ranked prey according to energy returns on the basis of small size prey's fast or slow locomotion. This ranking system allowed recognition of demographic pressure indicators and the identification of two distinct dietary change revolutions for the Mediterranean Basin: (1) from the Upper Palaeolithic to the Mesolithic, matching the time frame of Flannery's original conception of the Broad Spectrum Revolution; and (2) the transition from the Middle Palaeolithic to the Upper Palaeolithic, closely related with a renewed radiation of Anatomical Modern Humans from Africa into the Near East around 50-44,000 years BP (Stiner et al. 1999; Stiner - Kuhn 2006; Stiner - Munro 2011; Stiner - Munro - Starkovich.2012).

\section{PUSHING BACK BROAD SPECTRUM DIET CHRONOLOGIES}

Mary Stiner and colleagues have been pioneers in pushing back the notion of broad spectrum diets to late Neanderthal times. Increasing evidence has emerged mainly from the Mediterranean Basin, and faunal results obtained for sites in the Iberian Peninsula are extremely relevant.

In Portugal, indicators of wider Neanderthal diets were found in the first excavations of Gruta da Figueira Brava in the 1980s where a large variety of bird species was identified, together with several remains of rabbits, tortoises, marine mammals, marine molluscs and crabs (Antunes 2000, and papers therein). Nevertheless, such zooarchaeological research lacked detailed taphonomic studies, so it was difficult to assess if their presence was due to anthropogenic activity. Gruta Nova da Columbeira has a large collection of rabbit bones that seems to be due to human agency (Carvalho - Pereira - Manso 2018). The faunal assemblage also comprises tortoise remains, but according to Hockett and Haws (2009) it has not been confirmed that it was used as food. Conversely, a pilot study of the tortoise remains recovered from Gruta da Oliveira's layers 7 to 19 , recovered a total of 3,394 bone fragments. Based on stratigraphic association with Mousterian industry, Neanderthal remains and an in situ hearth on layer 14, together with evidences of cut marks and preferential burning on the exterior part of the carapace, such tortoise remains were interpreted as the result of Neanderthal consumption (Nabais 2012).

A large tortoise assemblage accumulated by hominins was also recovered from the Middle Palaeolithic levels of Cova del Bolomor (Valencia, Spain) where, together with confirmed bird consumption, it was possible to clearly demonstrate Neanderthal use of small prey (Blasco 2008; Blasco - Fernández Peris 2009; 2012a; 2012b; Blasco - Fernández Peris - Rosell 2010). Similar evidence was found in Gibraltar caves. Dorothy Garrod's excavations in the early $20^{\text {th }}$ century revealed a wide variety of species in Devil's Tower in stratigraphic association with Neanderthal human remains and Mousterian artefacts. Among the faunal assemblage, 25 mammal species were identified together with 33 bird species, including the currently extinct Pinguinus impennis (Linnaeus 1758), tortoise remains, fish and 
molluscs (Garrod et al. 1928). The Mousterian layers contained mussels and different species of limpets from both Atlantic and Mediterranean environments (Colonese et al. 2011). Marine resources were also found in recent excavations of Middle Palaeolithic levels of Gorham's Cave. They consist of rocky intertidal molluscs, such as limpets, mussels and topshells whose exploitation patterns seemed to have remained the same during Middle and Upper Palaeolithic times ( $\mathrm{Fa} 2008$ ). According to Stringer et al. (2008) marine mammals were also recovered from levels associated with Mousterian industry, as well as birds and rabbits with human gnawing marks. Currant and colleagues (Currant - Fernández-Jalvo - Price 2012) identified a long list of mammal remains, reinforcing the large number of rabbits present in the assemblage. Vanguard Cave shows a similar faunal composition, where terrestrial mammals shared the Mousterian levels with marine resources, including dolphins, seals, marine birds, fish, crabs and molluscs (Colonese et al. 2011; Currant et al. 2012; Stringer et al 2008). Most shells coincided with the spread of ashes from two underlying hearths; they were burnt or showed some sign of heating (Barton et al. 1999). Cueva de los Aviones (Murcia, Spain) has also a Neanderthal occupation associated with bone remains of horse, deer, ibex, rabbit, tortoise and marine molluscs (Zilhão et al. 2010). Among the latter, rocky species are the most abundant (mainly top snail, mussel and limpet) and seaweed was also identified, essentially Jania rubens (Montes Bernárdez 1989).

Although there is vast evidence of marine resources in hominin diets, only in 2001 was their relevance truly considered by Erlandson. Until then, marine resources were generally seen as less productive for hominin exploitation due to their small size, costly processing and unreliability (Erlandson 2001). They were also associated with women and children's work in most ethnographic societies (Meehan 1983; Siegfried Hockey 1985), which contradicted the established idea of male-dominated hunting as the central force of subsistence. Moreover, a diet based on shellfish is high in protein but low in fat, and Noli and Avery (1988) considered it to have severe health consequences.

However, it seems from ethnographic studies that many sea foods are storable and seasonally predictable (like salmon going up-stream) (Mannino Thomas 2002); shellfish is a predictable resource and has significant nutritional benefits due to richness in

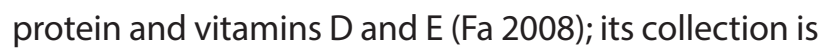
an easy and low-risk activity and many recent hunter-gatherers indicate that daily subsistence is based on resources like plants and small game, and not on medium to large game hunting (Bicho - Haws 2008). Furthermore, sea level today is at its highest point and most hominin coastal evidence is probably destroyed or submerged (Bailey - Flemming 2008; Bicho - Haws 2008; Colonese et al. 2011; Erlandson 2001). Recently, Mousterian artefacts were found eroding from a creek bank $18 \mathrm{~m}$ below sea level, close to Cherbourg, France (Flemming 1998, apud Erlandson 2001:327), and intact bone-bearing deposits in underwater caves near Gibraltar have been investigated (Erlandson - Fitzpatrick 2006). Finally, plate tectonics have also played a significant role and, according to Bailey and Flemming (2008), the Mediterranean region is in a main potential tectonic uplift zone, which helped preserve some of its archaeological deposits above present sea-level.

\section{CONSTRAINTS OF NEANDERTHAL CURRENT BROAD SUBSISTENCE MODELS}

Although there is increased evidence of wider hominin diets in earlier time periods, it seems that the most recent and accepted broad spectrum theories are still largely dependent on demographic pressure as the main engine for small size resource consumption. This is the trend even after ethnography has shown that small resources, like shellfish, should be ranked in higher positions since they are reliable, predictable, and not at all marginal or difficult alternatives in moments of crisis (Bicho - Haws 2008). Ethnography has also demonstrated that people are willing to walk long distances in order to collect their favourite molluscs. Once they reach intertidal zones, they often prefer some species above others that contain more meat. A good example is the Anbarra community in north Australia, where the consumption of the tapestry shell is preferred over the brown mussel that provides more energy (Meehan 1983). Hence, hunter-gatherers are subjected to the resources existing in their living environment, but they also have the free will to choose other resources that are not necessarily the most fit in terms of energy returns, but they can simply taste better. 
Another difficulty with broad spectrum diets relates to the amount of clear evidence for small game consumption, in which marine resources play an important role. Researchers working in Gibraltar were among the first to claim marine resources as highly important in hominin diets (Finlayson 2008; Stringer et al. 2008), an argument later followed by Cortéz-Sánchez et al. (2011) for the Bajondillo Cave, in Málaga (Spain). Both teams have shown Neanderthal's systematic use of seafood, and coastal adaptation through comparisons with the dense shellfish remains recovered from Middle Stone Age South African sites, like Sea Harvest (Volman 1978), Hoedjiespunt (Kyriacou et al. 2015; Will et al. 2013), Klasies River (Langejans et al. 2012; Thackeray 1988), Ysterfontein 1 (Klein et al. 2004), Pinnacle Point 13B (Jerardino - Marean 2010; Marean et al. 2007) or Blombos Cave (Langejans et al. 2012). In spite of the similarities in timeframe, such comparisons were not considered valid by Klein and Steele (2008: E115), who argued that Spanish caves did not have sufficient evidence for extensive shellfish exploitation. Marean (2014) further considers that the small amounts of molluscs are sparsely distributed and only found in thin lenses from large sedimentary deposits, not meeting the definition of a shell midden. Moreover, no definition of "systematic use" is given, revealing no understanding of the consequences of such behaviour.

Two problems arise from these criticisms: (1) the definition of a shell midden, and (2) the clear identification of a hunter-gatherer group's systematic coastal use. Shell middens were first designated in Danish as køkkenmødding, which means kitchen midden, referring to the food waste of people living by the sea and using its resources (Speed 1969). This is the generally accepted shell midden definition, but it is extremely broad and subjective. There were several attempts of better defining it, like Andersen (2007) who defines a shell midden as a cultural deposit in which at least $50 \%$ of the volume is made of shells forming a continuous horizon with a minimum of $10 \mathrm{~m}^{2}$. If a site fails on this number, then it should be considered as a shell bearing site. Other researchers tried to create shell midden typologies, such as Widmer (1989, apud Claassen 1998: 11) who distinguished between (a) shell midden sites, (b) shell middens, (c) shell bearing midden sites, and (d) shell bearing habitation sites, based on the distinction between site and deposit. Another categorisation is the one from Dupont (2006: 41), who establishes three types of shell middens according to morphology and volume: (1) Amas coquiller, a mound bigger than $2 \mathrm{~m}^{3}$; (2) Dépôt coquiller, a mound smaller than $2 \mathrm{~m}^{3}$; and (3) Lit coquiller, a horizontal shell layer. The lack of an accepted definition led Balbo et al. (2011) to propose a broad description of shell midden as an "intentional anthropogenic shell accumulation", so it can include all chronologies, geography, sizes and shapes. In the light of this recent definition, the above-mentioned Spanish caves would be accepted as shell middens, as well as their South African counterparts.

Concerning the systematic use of marine resources, it implies a designed subsistence strategy that would intercept the coast at determined periods of the year, sometimes shifting between inland and littoral, or even remaining at the coast all year (Marean 2014). Consequently, a sporadic use of the coast is not a systematic use. Primates (e.g. Russon et al. 2014) and other animals (Erlandson - Moss 2001) consume marine resources, but that does not mean they are coastal adapted or that they do it systematically. It should also be cautioned that ethnographic studies have shown that systematic use of costal resources generally result in highly sedentary behaviour with consequent population increase, highest levels of complexity, high technological developments and levels of conflict (Marean 2014).

So how can we identify systematic coastal resource use? Since many animals eat marine resources and are capable of forming small shell heaps, the first step is to clearly define the agent of accumulation. Coastal sites can also contain shell accumulations due to natural activities, like storms or sea high tides. It is fundamental to recognise stratigraphic association between bone/shell remains and well-dated lithic industry or other features, and to identify bone/shell surface modifications (like burning), patterns of mechanical fracture and any other visible taphonomic processes. Another valuable contribution is to report shell densities in comparison to the volume of sediment excavated. Although there are no magic numbers, they will give a feel for the intensity of shell accumulation. The cultural use of shells (i.e. as beads or as containers for ochre) can also be a good indicator of systematic use. A final approach is the use of scientific methods. Isotope analysis on hominin remains can easily tell if they 
were consuming marine resources, and isotope analyses on shells give precious information on seasonality, as well as permitting environmental reconstruction and discussion on hominin mobility strategies.

Systematic use of marine resources does not imply abandonment of terrestrial foods. However, the contribution of both types of resources should be analysed in detail. It is fundamental to study animal categories individually but also in an integrated manner, so that their contribution to hominin diets and consequent food provisioning strategies can be compared and contrasted in any possible way (e.g. type of environment, animal size, type of animal locomotion). Marine and terrestrial resources should also be assessed from a site formation process perspective through taphonomy, in order to confirm their use and accumulation by hominins.

\section{FORMATION OF FAUNAL ASSEMBLAGES}

Hominin behaviour is one of many potential agents of bone accumulation and modification. Associations of stone tools and faunal remains are still generally accepted as sufficient to infer on hominin meat-procurement and consumption. However, such perception has been criticised since the 1980 s by several authors (e.g. Bailey 1983; 2007; Marshall 1989) who argue that the finds should be put into site specific context, bearing in mind the environment of the deposition and all possible site formation processes. Consequently, all zooarchaeological analyses should have as their primary concern the use of an explicit and detailed taphonomic methodology, considering all different scenarios regarding bone assemblage formation.

Several natural causes can be responsible for bone accumulation. Assemblages can be formed by natural deaths: whether catastrophic, and therefore concerning several animals; or due to the normal death of an individual. For the first scenario, Conybeare and Haynes (1984) studied mortality profiles caused by mass death events, such as flash floods. The resulting faunal assemblages are characterised by the presence of several species inhabiting the area at the time the floods occurred; there should be variation in terms of sex and age-structure, since there was no specific animal targeting and the whole population was indifferently killed. Haynes (1988) further refers that such events would produce an important opportunity for countless predators. However, low carnivore marks would be found since predators-scavengers would not feed intensively on each of them since there are plenty available. Natural fires can also decimate a population, as it is reported for tortoise populations in South Africa (Avery et al. 2004), France and Spain (Couturier et al. 2014). Assemblages resulting from such events feature individuals of all sexes and ages, with skeletons still in articulation exhibiting completely charred bones. Conversely, each animal can reach the end of its life due to many other causes related to the general health of each individual - disease, old age, hibernation, among others -, and are thus the opposite of the catastrophic scenario. In such cases it is expected to find more restricted age structures with preference for very old or very young animals, and absence of prime-age individuals that are generally more resilient. Males and females should be equally represented, and predator-scavenger and hominin bone modifications may overlap (Conybeare - Haynes 1984). Additionally, accidental deaths due to natural traps (such as pitfalls) should also be considered. Some excellent examples are the ones provided by leporid remains recovered from the French caves of Coudoulous II (Cochard 2004), Igue des Rameaux (Cochard 2004), Régourdou (Pelletier et al. 2015), Igue du Gral (Castel et al. 2014) and Coulet des Roches (Pelletier et al. 2020). The taphonomic signature of such remains revealed high completeness of the bones showing low degree of bone surface modification, mostly related with natural phenomena or post-mortem events, as well as mortality profiles compatible with a natural living population structure.

Archaeological material can also be naturally transported by physical action due to run-off, aeolian, fluvial or tidal processes resulting in accumulations of derived position and thus forming secondary deposits. Archaeological materials are expected to be found following an orientation aligned with the direction of the movement flow; lighter elements (e.g. vertebrae) tend to travel longer distances than denser elements (e.g. teeth) that are generally accumulated in in lag deposits; and transported elements can show rounding of the edges, with different degrees of erosion associated with the distance travelled, i.e. short distances corresponding to low rounding degrees, and vice-versa 
(Auguste 1995; Stopp 1997). Due to its secondary deposition, faunal remains with anthropogenic and/ or predator-scavenger surface modifications relate to events performed elsewhere other than the location where they were recovered. Therefore, such behaviours should be interpreted with caution since they cannot necessarily provide information on subsistence on the locale where faunal remains were found. Additionally, when digging in cave environments, one should also consider vertical movements. These are frequently produced by (a) accumulations close to cave walls, (b) roof collapses, and (c) sediment slide through cave cracks and fissures that can result in hourglass-shaped accumulations (such as the one found in layers 26 and 27 from the Middle Palaeolithic site of Gruta da Oliveira (e.g. Deschamps - Zilhão 2018).

The predator-scavenger scenario refers to faunal accumulations due to carnivore/raptor feeding behaviours. It is marked by extensive evidence of predator-scavenger modifications, such as gnawing, pitting, punctures, edge crenulations, scores, digestion; mostly confined to the meatiest areas of the bones indicating primary access to the carcass; and should be present in most skeletal elements and species found on site (e.g. Binford 1981; Brain 1981). Most frequently, such accumulations are due to the activity of hyenids, canids and felids that show different accumulation characteristics (Auguste 1995). For example, faunal assemblages formed by hyenas are marked by the lack of long bone epiphyses, mainly the proximal ends of humeri and tibiae, the distal radii and both ends of the femuri which are frequently chewed off (e.g. Bunn 1986; Cruz-Uribe 1991; Pickering 2002). In addition, the presence of juvenile hyena bones, as well as some cannibalistic hyena behaviour, are accepted as evidence of hyena dens (e.g. Diedrich 2011; Pickering 2002). Adding to previous studies (e.g. Haynes 1982; 1983; Mondini 2000; 2004; Mondini - Sebastian Muñoz 2007), extensive experimental work has been carried out in the last decade on carnivore/raptor bone accumulations focusing, not only on bone surface modification, but also on skeletal part representation patterns (e.g. Arilla et al. 2019; Camarós et al. 2017; Lloveras - Moreno García - Nadal 2009; Mallye et al. 2012; Rodríguez-Hidalgo et al. 2020; Sanchis et al. 2014; Stiner - Munro - San. 2012). Such studies have been essential in the separation of faunal accumulations by very different predators - from larger animals (like lions and hyenas) to smaller species (lynx, eagles, badgers and several others).

Finally, the hominin scenario shows anthropic accumulation of faunal remains as direct result of subsistence behaviour on site. In such instances, it is expected to find anthropogenic marks (like incisions and intentional burning) on bones and shells demonstrating primary access to the carcass, i.e. modifications on the meatiest parts (Domínguez-Rodríguez 1999; 2003). There should be numerous hominin modifications distributed across most elements and species, whereas carnivore marks should be limited and restricted to elements with low bearing meat. Whenever both signatures are present, the carnivore marks should overlie hominin modifications (Binford 1981). However, it should be borne in mind that humans can produce modifications similar to carnivores. Hence, it is important to separate them neatly, especially when considering tooth marks (Fernández-Jalvo - Andrews 2011; Saladié et al. 2013).

\section{RECENT RESEARCH AND CLOSING REMARKS}

It is now clear that to fully understand the role hominins played in faunal accumulations, they have to be put into site-specific and palaeoenvironmental contexts in which it can be determined who was the agent responsible for the formation of faunal assemblages. This has been made easier in the last years considering the large amount of actualistic studies providing detailed insight into the patterns and signatures created by several specific agents of accumulation in the archaeological record (e.g. see the extensive work of Lluís Lloveras researching on rabbit bone accumulators).

The review of the ongoing debates regarding hominin diets has shown that both hunting and scavenging subsistence strategies might have been concurrently performed since there is no archaeological evidence disproving any of the models, but rather suggests that they may have complemented each other. Such food procurement models were certainly part of a larger behavioural framework that included subsistence and environmental adaptive strategies depending on the geographical setting that was being explored. 
Such a notion has been recently demonstrated by the results provided from the last fieldwork seasons (2010-2013) in Gruta da Figueira Brava, in Portugal. Zilhão et al. (2020) established that Last Interglacial Iberian Neanderthals exploited the full range of ecosystems present in their ecotonal environment. Fishing and seafood harvesting were accomplished systematically, and were complemented with mammal and bird hunting, as well as fruit collection. The observed diversity of food resources consumed in Gruta da Figueira Brava by Neanderthals is higher than that found at nearby Mesolithic sites dated to between 7500 and 9000 years ago. During the phases of more intensive occupation, the Figueira Brava mollusc accumulations are as dense as in those Mesolithic sites, in which isotope analysis of human bone reflects a diet that was of up to $50 \%$ of marine origin. Additionally, in Gruta da Oliveira, in an inland setting, it was tortoises that had a paramount role in the Neanderthals' exploitation of small game. Large size individuals seem to have been preferentially targeted, indicating a predilection for adult animals. The consumption of tortoises may have had an impact on the local population, as possibly suggested by the decrease in size and in number of remains from the older to the most recent occupations (Nabais - Zilhão 2019).

The most recent results from these two Portuguese Neanderthal caves agree with the growing corpus of Eurasian literature that challenges previous interpretations of Neanderthal preferential targeting of large and medium ungulates. In the Mediterranean Basin, and the Iberian Peninsula in particular, it is clear that Neanderthals had a broad spectrum subsistence where all kinds of animal food resources were procured and included in the diet. Neanderthal exploitation encompassed all ungulate sizes (from very large, e.g., rhinoceros, to small, e.g. ibex) and extended to slow and quick moving small vertebrates (like tortoises and birds, respectively), and to several aquatic animals (aquatic birds, fishes, several molluscs and crabs).

The confirmation of certain qualities in Neanderthal subsistence strategies, like (1) their adaptability to the varied resources available in the landscape, (2) their broad spectrum diets, (3) the hunting of small fast game, (4) the systematic use of marine resources, (5) the recurrent use of the same sites at different times of the year, have been considered by many researchers as part of a modern behaviour package (e.g. Klein Steele 2008; Marean 2014; Mellars 2007). That Neanderthals were endowed with symbolic thinking is revealed by the practice of personal ornamentation and burial (e.g. Hoffmann et al. 2018a; Vanhaeren et al. 2006; Zilhão et al. 2010), their controlled use of fire (e.g. Sorensen - Claud - Soressi 2018; Villa - Roebroeks 2014), complex lithic technology (e.g. d'Errico - Borgia - Ronchitelli 2012; Zilhão et al. 2015), extensive social networks (e.g. Villa - Roebroeks 2014) and production of art (e.g. Hoffmann et al. 2018b; Prévost et al. 2021;), all of which have been considered feature-specific of "modern humans". Such seems to be also the case for Neanderthal lifeways and subsistence economy, adding support to the notion that Neanderthals were humans just like us.

\section{References}

ANDERSEN, S. (2007) - Shell middens (Køkkenmøddinger) in Danish Prehistory as a reflection of the marine environment. In MILNER, N. - CRAIG, O. - BAILEY, G. (eds) - Shell Middens in Atlantic Europe. Oxford: 31-45.

ANTUNES, M. (2000) - Last Neanderthals in Portugal. Odontologic and Other Evidence (Classe das Ciências, Tomo XXXVIII). Lisboa.

ARILLA, M. - RUFÀ, A. - ROSELL, J. - BLASCO, R. (2019) - Small carnivores' cave-dwelling: neo-taphonomic study of a badger (Meles meles) sett and its archaeological implications. Historical Biology: 1-15.

AUGUSTE, P. (1995) - Chasse ou charognage au Paléolithique moyen: l'apport du gisement de Bianche-Saint-Vaast (Pas-de-Calais). Bulletin de la Société Préhistorique Française, 92, 2: 155-168.

AVERY, G. - KANDEL, A. - KLEIN, R. - CONRAD, N. - CRUZ-URIBE, K. (2004) - Tortoises as food and taphonomic elements in palaeo «landscapes». In BRUGAL J.P. - DESSE J., (eds.) - Petits Animaux et Sociétés Humaines. Du Complément Alimentaire aux Resources Utilitaires. Antibes: 147-161.

BAILEY, G. (1983) - Concepts of time in Quaternary Prehistory. Annual Review of Anthropology, 12: 165-192.

BAILEY, G. (2007) - Time perspectives, palimpsests and the archaeology of time. Journal of Anthropological Archaeology, 26: $198-223$

BAILEY, G. - FLEMMING, N. (2008) - Archaeology of the continental shelf: Marine resources, submerged landscapes and underwater archaeology. Quaternary Science Review, 27: 2153-2165.

BALBO, A. - MADELLA, M. - GODINO, I. - ÁLVAREZ, M. (2011) Shell midden research: An interdisciplinary agenda for the Quaternary and Social Sciences. Quaternary International, 239: 147-152.

BARTON, R. - CURRANT, A. - FERNÁNDEZ-JALVO, Y. - FINLAYSON, C. - GOLDBERG, P. - MACPHAIL, R. - PETTIT, P. - STRINGER, C. (1999) - Gibraltar Neanderthals and results of recent excavations in Gorham's, Vanguard and Ibex Caves. Antiquity, 73: 13-23. 
BICHO, N. - HAWS, J. (2008) - At the land's end: Marine resources and the importance of fluctuations in the coastline in the prehistoric hunter-gatherer economy of Portugal. Quaternary Science Review, 27: 2166-2175.

BINFORD, L. (1968) - Post-Pleistocene adaptations. In BINFORD, L. - BINFORD, S. (eds.) - New Perspectives in Archaeology. Chicago: 313-341.

BINFORD, L. (1978) - Nunamiut Ethnoarchaeology. New York.

BINFORD, L. (1981) - Bones: ancient men and modern myths. Orlando.

BINFORD, L. (1984) - Faunal Remains from Klasies River Mouth. New York.

BINFORD, L. (1985) - Human ancestors: Changing views of their behaviour. Journal of Anthropological Archaeology, 4: 292-327.

BINFORD, L. (1987) - Were there elephant hunters at Torralba? In NITECKI, M. - NITECKI, D. (eds.) - The evolution of human hunting. New York/ London: 47-105.

BLASCO, R. (2008) - Human consumption of tortoises at Level IV of Bolomor Cave (Valencia, Spain). Journal of Archaeological Science, 35: 2839-2848.

BLASCO, R. - FERNÁNDEZ PERIS, J. (2009) - Middle Pleistocene bird consumption at Level XI of Bolomor Cave (Valencia, Spain). Journal of Archaeological Science, 36: 2213-2223.

BLASCO, R. - FERNÁNDEZ PERIS, J. (2012a) - Small and large game: Human use of diverse faunal resources at Level IV of Bolomor Cave (Valencia, Spain). Comptes Rendus Palevol, 11: 265-282.

BLASCO, R. - FERNÁNDEZ PERIS, J. (2012b) - A uniquely broad spectrum diet during the Middle Pleistocene at Bolomor Cave (Valencia, Spain). Quaternary International, 252: 16-31.

BLASCO, R. - FERNÁNDEZ PERIS, J. - ROSELL, J. (2010) - Several different strategies for obtaining animal resources in the late Middle Pleistocene: The case of level XII at Bolomor Cave (Valencia, Spain). Comptes Rendus Palevol, 9: 171-184.

BLASCO, R. - ROSELL, J. - RUFÀ, A. - SÁNCHEZ MARCO, A. FINLAYSON, C. (2016) - Pigeons and choughs, a usual resource for the Neanderthals in Gibraltar. Quaternary International, 421: 62-77.

BLUMENSCHINE, R., 1986. Early hominid scavenging opportunities: Implications of carcass availability in the Serengerti and Ngorongoro ecosystems (BAR International Series 283). Oxford.

BLUMENSCHINE, R. (1992) - Hominid carnivory and foraging strategies and the socio-economic function of early archaeological sites. In WHITTEN, A. - WIDDOWSON, E. (eds.) - Foraging strategies and natural diet of monkeys, apes and humans. Oxford: 51-61.

BOCHERENS, H. (2009) - Neanderthal Dietary Habits: Review of the Isotopic Evidence. In HUBLIN, J. - RICHARDS, J. (eds.) - The Evolution of Hominin Diets. Integrating Approaches to the Study of Palaeolithic Subsistence. London: 241-250.

BOCHERENS, H. - FIZET, M. - MARIOTTI, A. - LANGE-BADRÉ, B. - VANDERMEERSCH, B. - BOREL, J. P. - BELLON, G. (1991) Isotopic biochemistry $\left({ }^{13} \mathrm{C},{ }^{15} \mathrm{~N}\right)$ of fossil vertebrate collagen; implications for the study of fossil food web including Neandertal man. Journal of Human Evolution, 20: 481-492.

BRAIDWOOD, R. (1960) - The agricultural revolution. Scientific American, 203: 130-141.

BRAIDWOOD, R. (1963) - Prehistoric Men (Popular Series, Anthropology n. 37). Chicago.

BRAIN, C. (1981) - The Hunters or the Hunted? An Introduction to African Cave Taphonomy. Chicago.
BUNN, H. - (1986) - Patterns of Skeletal Representation and Hominid Subsistence Activities at Olduvai Gorge, Tanzania, and Koobi Fora, Kenya. Journal of Human Evolution, 15: 673-690.

BURKE, A. (2004) - The ecology of Neanderthals: Preface. International Journal of Osteoarchaeology, 14:155-161.

CAMARÓS, E. - CUETO, M. - TEIRA, L. - MÜNZEL, S. - PLASSARD, F. - ARIAS, P. - RIVALS, F. (2017) - Bears in the scene: Pleistocene complex interactions with implications concerning the study of Neanderthal behaviour. Quaternary International, 435: 237-246.

CARVALHO, M. - PEREIRA, T. - MANSO, C. (2018) - Rabbit exploitation in the Middle Paleolithic at Gruta Nova da Columbeira, Portugal. Journal of Archaeological Science: Reports, 21: 821-832. DOI: https://doi.org/10.1016.j.jas rep.2018.09.003

CASTEL, J. C. - BOUDADI-MALIGNE, M. - DUCASSE, S. - RENARD, C. - CHAUVIĖRE, F. X. - KUNTZ, D. - MALLYE, J. B. (2014) - Animal Exploitation Strategies in Eastern Aquitaine (France) during the Last Glacial Maximum. In FOULDS, F. W. F. - DRINKALL, H. C. - PERRI, A. R. - CLINNICK, D. T. G. - WALKER, J. W. P. (eds.) Wild things. Recent advances in Palaeolithic and Mesolithic research. Oxford: 160-174.

CHRISTENSON, A. (1980) - Change in the human food niche in response to population growth. In EARLE, T. - CHRISTENSON, A. (eds.) - Modeling Change in Prehistoric Subsistence Economies. New York: 31-72.

CLAASSEN, C. (1998) - Shells. Cambridge University Press

CLARK, G. - STRAUS, L. (1986) - Synthesis and Conclusions - Part I: Upper Paleolithic and Mesolithic Hunter-Gatherer Subsistence in Northern Spain. In STRAUS, L. - CLARK, G., La Riera Cave. Stone Age Hunter-Gatherer Adaptations in Northern Spain. Arizona (Anthropological Research Papers, 36): 351-365.

COCHARD, D. (2004) - Les léporidés dans la subsistance paléolithique du Sud de la France. PhD Thesis. Université de Bordeaux I, Talence.

COHEN, M. (1977) - Food Crisis in Prehistory. New Haven and London.

COLONESE, A. - MANNINO, M. - BAR-YOSEF MAYER, D. - FA, D. - FINLAYSON, J. - LUBELL, D. - STINER, M. (2011) - Marine mollusc exploitation in Mediterranean prehistory: An overview. Quaternary International, 239: 86-103.

CONYBEARE, A. - HAYNES, G. (1984) - Observations on elephant mortality and bones in water holes. Quaternary Research, 22: 189-200.

CORTÉZ-SÁNCHEZ, M. - MORALES-MUÑIZ, A. - SIMÓN-VALLEJO, M. - LOZANO-FRANCISCO, M. - VERA-PELÁEZ, J. - FINLAYSON, C. - RODRÍGUEZ-VIDAL, J. - DELGADO-HUERTAS, A. - JIMÉNEZ-ESPEJO, F. - MARTÍNEZ-RUIZ, F. - MARTÍNEZ-AGUIRRE, M. - PASCUAL-GRANGED, A. - BERGADÀ-ZAPATA, M. - GIBAJA-BAO, J. - RIQUELME-CANTAL, J. - LÓPEZ-SÁEZ, A. - RODRIGO-GÁMIZ, M. - SAKAI, S. - SUGISAKI, S. a - FINLAYSON, G. - FA, D. - BICHO, N. (2011) - Earliest Known Use of Marine Resources by Neanderthals. PLOS ONE, 6: 1-15.

COUTURIER, T. - BESNARD, A. - BERTOLERO, A. - BOSC, V. ASTRUC, G. - CHEYLAN, M. (2014) - Factors determining the abundance and occurrence of Hermann's tortoise Testudo hermanni in France and Spain: Fire regime and landscape changes as the main driver. Biological Conservation, 170: 177-187.

CRUZ-URIBE, K. (1991) - Distinguishing Hyena from Hominid Bone Accumulations. Journal of Field Archaeology, 18: 467-486. 
CURRANT, A. - FERNÁNDEZ-JALVO, Y. - PRICE, C. (2012a) The large mammal remains from Vanguard Cave. In BARTON, R. - STRINGER, C. - FINLAYSON, C. (eds.) - Neanderthals in Context. A report of the 1995-1998 excavations at Gorham's and Vanguard Caves, Gibraltar. Oxford: 236-239.

CURRANT, A. - PRICE, C. - SUTCLIFFE, A. - STRINGER, C. (2012b) The large mammal remains from Gorham's Cave. In BARTON, R. - STRINGER, C. - FINLAYSON, C. (eds.) - Neanderthals in Context. A report of the 1995-1998 excavations at Gorham's and Vanguard Caves, Gibraltar. Oxford: Oxford University School of Archaeology, pp. 141-150.

D'ERRICO, F. - BORGIA, V. - RONCHITELLI, A. (2012) - Uluzzian bone technology and its implications for the origin of behavioural modernity. Quaternary International, 259: 59-71.

DART, R. (1959) - Further light on Australopithecine humeral and femoral weapons. American Journal of Physical Anthropology, 17: 87-94.

DARWIN, C. (1871) - The Descent of Man, and Selection in Relation to Sex. Princeton

DESCHAMPS, M. - ZILHÃO, J. (2018) - Assessing site formation and assemblage integrity through stone tool refitting at Gruta da Oliveira (Almonda karst system, Torres Novas, Portugal): A Middle Paleolithic case study. PLoS ONE, 13: e0192423. DOI: https://doi.org/10.1371/journal.pone. 0192423

DIEDRICH, C. (2011) - Pleistocene Panthera leo spelaean (Goldfuss 1810) remains from the Balve cave (NW Germany) - a cave bear, hyena den and Middle Palaeolithic human cave - and review of the Sauerland Karst lion cave sites. Quaternaire, 22: 105-127.

DISCAMPS, E. - JAUBER, J. - BACHELLERIE, F. (2011) - Human choices and environmental constraints: deciphering the variability of large game procurement from Mousterian to Aurignacian times (MIS 5-3) in southwestern France. Quaternary Science Reviews, 30, 2755-2775. DOI: https://doi. org/10.1016/j.quascirev.2011.06.009

DOMÍNGUEZ-RODRIGO, M. (1999) - Distinguishing between apples and oranges: The application of modern cut mark studies to the Plio-Pleistocene (a reply to Monahan). Journal of Human Evolution, 33: 793-800.

DOMÍNGUEZ-RODRIGO, M. (2002) - Hunting and Scavenging by Early Humans: the State of the Debate. Journal of World Prehistory, 40: 77-98.

DOMÍNGUEZ-RODRIGO, M. (2003) - On cut marks and statistical inferences: Methodological comments on Lupo - O'Connell (2002). Journal of Archaeological Science, 30: 381-386.

DUPONT, C. (2006) - La malacofaune de sites mésolithiques et néolithiques de la façade atlantique de la France: contribution à l'économie et à l'identité culturelle des groupes concernés (BAR International Series 1571). Oxford.

ECKER, M. - BOCHERENS, H. - JULIEN, M. A. - RIVALS, F. RAYNAL, J. - MONCEL, M. H. (2013) - Middle Pleistocene ecology and Neanderthal subsistence: insights from stable isotope analyses in Payre (Ardèche, southeastern France). Journal of Human Evolution, 65: 363-373.

ERLANDSON, J. (2001) - The Archaeology of Aquatic Adaptations: Paradigms for a New Millennium. Journal of Archaeological Research, 4: 287-350.

ERLANDSON, J. - FITZPATRICK, S. (2006) - Oceans, Islands, and Coasts: Current Perspectives on the Role of the Sea in Human Prehistory. Journal of Island - Coastal Archaeology, 1: 5-32.
ERLANDSON, J. - MOSS, M. (2001) - Shellfish feeders, carrion eaters, and the archaeology of aquatic adaptations. American Antiquity, 66: 413-432.

FA, D. (2008) - Effects of the tidal amplitude on intertidal resource availability and dispersal pressure in prehistoric human coastal populations: the Mediterranean-Atlantic transition. Quaternary Science Review, 27: 2194-2209.

FARIZY, D. - DAVID, F. - JAUBERT, J. (1994) - Hommes et Bisons du Paléolithique Moyen à Mauran (Haute-Garonne). Paris (Gallia Préhistoire, Supplément 30).

FERNÁNDEZ-JALVO, Y. - ANDREWS, P. (2011) - When humans chew bones. Journal of Human Evolution, 60: 117-123.

FINLAYSON, C. (2008) - On the importance of coastal areas in the survival of Neanderthal populations during the Late Pleistocene. Quaternary Science Reviews, 27: 2246-2252.

FLANNERY, K. (1969) - Origins and ecological effects of early domestication in Iran and the Near East. In UCKO, P. DIMBLEBY, G. (eds.) - The domestication and exploitation of plants and animals. London: 73-100.

FLEMMING, N. C. (1998) - Archaeological evidence for vertical movement on the continental shelf during the Palaeolithic, Neolithic and Bronze Age periods. In STEWART, I. S. VITA-FINZI, C. (eds.) - Coastal Tectonics.. London (Geological Society Special Publications, 146: 129-146.

GARROD, D. - BUXTON, L. - SMITH, G. - BATE, D. - SPILLER, R. HINTON, M. - FISCHER, P. (1928) - Excavation of a Mousterian Rock-Shelter at Devil's Tower, Gibraltar. The Journal of the Royal Anthropological Institute of Great Britain and Ireland, 58: 33-113.

GAUDZINSKI, S. (1996) - On bovid assemblages and their consequences for the knowledge of subsistence patterns in the Middle Palaeolithic. Proceedings of the Prehistoric Society, 62: 19-39.

GAUDZINSKI, S. (2004) - A matter of high resolution? The Eemian interglacial (OIS 5e) in north-central Europe and Middle Palaeolithic subsistence. International Journal of Osteoarchaeology, 14: 201-211.

GAUDZINSKI-WINDHEUSER, S. - KINDLER, L. (2012) - Research perspectives for the study of Neanderthal subsistence strategies based on the analysis of archaeozoological assemblages. Quaternary International, 247: 59-68. DOI: https://doi.org/10.1016/j.quaint.2010.11.029

GAUDZINSKI-WINDHEUSER, S. - NIVEN, L. (2009) - Hominin and Subsistence Patterns During the Middle and Late Palaeolithic in Northwestern Europe. In HUBLIN, J. J. RICHARDS, M. P. (eds.) - The Evolution of Hominid Diets: Integrating Approaches to the Study of Palaeolithic Subsistence. London: 97-109.

HARDY, B. (2010) - Climatic variability and plant food distribution in the Pleistocene Europe: implications for Neanderthal diet and subsistence. Quaternary Science Reviews, 29: 622-679.

HARDY, B. - MONCEL, M. H. (2011) - Neanderthal use of fish, mammals, birds, starchy plants and wood 125-250,000 years ago. PLOS ONE, 6: e23768.

HARDY, B. - MONCEL, M. H. - DAUJEARD, C. - FERNANDES, P. BÉAREZ, P. - DESDAUX, E. - CHACÓN NAVARRO, M. - PUAUD, S. - GALLOTTI, R. (2013) - Impossible Neanderthals? Making string, throwing projectiles and catching small game during Marine Isotope Stage 4 (Abri du Maras, France). Quaternary Science Reviews, 82: 23-40. DOI: https://doi.org/10.1016/j. quascirev.2013.09.028 
HARDY, K. - BUCKLEY, S. - COLLINS, M. - ESTALRRICH, A. - BROTHWELL, D. - COPELAND, L. - GARCÍA-TABERNERO, A. - GARCÍA-VARGAS, S. - DE LA RASILLA, M. - LALUEZA-FOX, C. - HUGUET, R. - BASTIR, M. - SANTAMARÍA, D. - MADELLA, M. - WILSON, J. - FERNÁNDEZ CORTÉS, Á. - ROSAS, A. (2012) - Neanderthal medics? Evidence for food, cooking, and medicinal plants entrapped in dental calculus. Naturwissenschaften, 99: 617-626.

HARDY, K. - RADINI, A. - BUCKLEY, S. - SARIG, R. - COPELAND, L. - GOPHER, A. - BARKAI, R. (2016) - Dental calculus reveals potential respiratory irritants and ingestion of essential plant-based nutrients at Lower Palaeolithic Qesem Cave Israel. Quaternary International, 398: 129-135.

HART, D. - SUSSMAN, R. (2005) - Man the Hunted: Primates, Predators and Human Evolution. New York.

HAYNES, G. (1982) - Utilization and skeletal disturbances of North American prey carcasses. Artic, 35: 266-281.

HAYNES, G. (1983) - A guide for differentiating mammalian carnivore taxa responsible for gnaw damage in herbivore limb bones. Paleobiologie, 9: 164-172.

HAYNES, G. (1988) - Mass deaths and serial predation: Comparative taphonomic studies of modern large mammal death sites. Journal of Archaeological Science, 15: 219-235.

HENRY, A. - BROOKS, A. - PIPERNO, D. (2011) - Microfossils in calculus demonstrate consumption of plants and cooked foods in Neanderthal diets (Shanidar III, Iraq; Spy I and II, Belgium). Proceedings of National Academy of Sciences, 108: 486-491.

HENRY, A. - BROOKS, A. - PIPERNO, D. (2014) - Plant foods and the dietary ecology of Neanderthals and early modern humans. Journal of Human Evolution, 69: 44-54.

HOCKETT, B. - HAWS, J. (2009) - Continuity in animal resource diversity in the Late Pleistocene human diet of Central Portugal. Before Farming, 2: 1-14.HOFFMANN, D. - ANGELUCCI, D. VILLAVERDE, V. - ZAPATA, J. - ZILHÃO, J., 2018a. Symbolic use of marine shells and mineral pigments by Iberian Neanderthals 115,000 years ago. Science Advances, 4: eaar5255.

HOFFMANN, D. - STANDISH, C. - GARCÍA-DIEZ, M. - PETTITT, P. - MILTON, J. - ZILHÃO, J. - ALCOLEA-GONZÁLEZ, J. CANTALEJO-DUARTE, P. - COLLADO, H. - BALBÍN R. LORBLANCHET, M. - RAMOS-MUÑOZ, J. - WENINGER, G.C. - PIKE, A. (2018b) - U-Th dating of carbonate crusts reveals Neandertal origin of Iberian cave art. Science, 359: 912-915. DOI: https://doi.org10.1126/science.aap7778

ISAAC, G. (1978) - The food-sharing behaviour of protohuman hominids. Scientific American, 238: 90-108.

ISAAC, G. (1982) - The archaeology of human origins. World Archaeology, 3: 1-87.

ISAAC, G. (1983) - Bones in Contention: Competing explanations for the juxtaposition of Early Pleistocene artefacts and faunal remains. In CLUTTON-BROCK, J. - GRIGSON, C. (eds.) - Animals and Archaeology 1: Hunters and their prey. Oxford (BAR International Series 163): 4-20.

ISAAC, G. - CRADER, D. (1981) - To what extent were early hominids carnivorous? An archaeological perspective. In HARDING, R. - TELEKI, G. (eds.), Omnivorous Primates: Gathering and hunting in human evolution. New York:37-103.

JAUBERT, J. - LORBLANCHET, M. - TURQ, A. - BRUGAL, J.P. (1990) Les Chasseurs d'Aurochs de la Borde. Paris.

JERARDINO, A. - MAREAN, C. (2010) - Shellfish gathering, marine palaeoecology and modern human behavior: perspectives from cave PP13B, Pinnacle Point, South Africa. Journal of Human Evolution, 59: 412-424.
KINDLER, L. - SMITH, G. M. - WAGNER, M. (2014) - Introduction to faunal analysis at Neumark-Nord 2. In GAUDZINSKI-WINDHEUSER, S. - ROEBROEKS, W. (eds.) - Multidisciplinary Studies of the Middle Palaeolithic Record from Neumark-Nord (Germany), Vol. 1, Band 69. Halle: 197-211.

KLEIN, R. - STEELE, T. (2008) - Gibraltar data are too sparse to inform on Neanderthal exploitation of coastal resources. Proceedings of the National Academy of Science of the United States of America, 105: letter E115.

KLEIN, R. - AVERY, G. - CRUZ-URIBE, K. - HALKETT, D. PARKINGTON, J. - STEELE, T. - VOLMAN, T. - YATES, R. (2004) - The Ysterfontein 1 Middle Stone Age site, South Africa, and early human exploitation of coastal resources. Proceedings of the National Academy of Science of the United States of America, 101: 5708-5715.

KYRIACOU, K. - PARKINGTON, J. - WILL, M. - KANDEL, A. - CONRAD, N. (2015) - Middle and Later Stone Age shellfish exploitation strategies and coastal foraging at Hoedjiespunt and Lynch Point, Saldanha Bay, South Africa. Journal of Archaeological Science, 57: 197-206.

LANGEJANS, G. - NIEKERK, K. - DUSSELDORP, G. a - THACKERAY, J. (2012) - Middle Stone Age shellfish exploitation: Potential indications for mass collecting and resource intensification at Blombos Cave and Klasies River, South Africa. Quaternary International, 270: 80-94.

LEE, R. B. - DEVORE, I. (eds.) (1968) - Man the Hunter. Chicago.

LLOVERAS, L. - MORENO-GARCÍA, M. - NADAL, J. (2009a) Butchery, Cooking and Human Consumption Marks on Rabbit (Oryctolagus cuniculus) Bones: An experimental study. Journal of Taphonomy, 7: 179-201.

MALLYE, J. B. - COSTAMAGNO, S. - BOUDADI-MALIGNE, M. PRUCCA, A. - LAUROULANDIE, V. - THIÉBAUT, C. - MOURRE, V. (2012) - Dhole (Cuon alpinus) as a bone accumulator and new taphonomic agent? The case of Noisetier Cave (French Pyrenees). Journal of Taphonomy, 10: 317-347.

MANNINO, M. - THOMAS, K. (2002) - Depletion of a resource? The impact of prehistoric human foraging on intertidal mollusc communities and its significance for human settlement, mobility and dispersal. World Archaeology, 33: 452-474.

MAREAN, C. W. (2014) - The origins and significance of coastal resource use in Africa and Western Eurasia. Journal of Human Evolution, 77: 17-40. DOI: https://doi.org/10.1016/j. jhevol.2014.02.025

MAREAN, C. W. - BAR-MATTHEWS, M. - BERNATCHEZ, J. FISHER, E. - GOLDBERG, P. - HERRIES, A. - JACOBS, Z. JERARDINO, A. - KARKANAS, P. - MINICHILLO, T. - NILSSEN, P. - THOMPSON, E. - WATTS, I. - WILLIAMS, H. (2007) Early human use of marine resources and pigment in South Africa during the Middle Pleistocene. Nature, 449: 905-908.

MARSHALL, L. (1989) - Bone modification and "the laws of burial". In BONNICHSEN, R. - SORG, M. (eds.) - Bone Modification. Orono: 7-24.

MEEHAN, B. (1983) - A matter of choice? Some thoughts on shell gathering strategies in northern Australia. In GRIGSON, C. - CLUTTON-BLOCK, J. (eds.), Animals and Archaeology 2: Shell middens, fishes and birds. Oxford (British Archaeological Reports, International Series 183): 3-17.

MELLARS, P. (1996) - The Neanderthal Legacy: An archaeological perspective from western Europe. Princeton. 
MELLARS, P. (2007) - Rethinking the Human Revolution: Eurasian and African Perspectives. In MELLARS, P. - BOYLE, K. BAR-YOSEF, O. - STRINGER, C. (eds.) - Rethinking the Human Revolution. Cambridge: 1-11.

MELLARS, P. - STRINGER, C. (1989) - The Human Revolution: Behavioural and biological perspectives on the origins of Modern Humans. Edinburgh.

MONDINI, M. (2000) - Tafonomía de abrigos rochosos de la Puna. Formación de conjuntos escatológicos por zorros y sus implicaciones arqueológicas. Arqueofauna, 9: 151-164.

MONDINI, M. (2004) - Accumulation of small and large vertebrates by carnivores in Andean South America. In BRUGAL, J. P. DESSE, J. (eds.) - Petits Animaux et Sociétés Humaines. Du Complément Alimentaire aux Ressources Utilitaires. Actes des XXIVèmes Rencontres Internationales d'Archéologie et d'Histoire d'Antibes. Antibes: 513-517.

MONDINI, M. - SEBASTIÁN MUÑOZ, A. (2007) - Pumas as taphonomic agentes: a comparative analysis of actualistic studies in the Neotropics. Quaternary Internatioanl, 180: 52-62.

MONTES BERNÁRDEZ, R. (1989) - La grotte "de Los Aviones", Cartagena (Espagne). Bulletin de la Société Préhistorique Française, Tome 86 (2): 40-44.

NABAIS, M. (2012) - Middle Palaeolithic Tortoise Use at Gruta da Oliveira (Torres Novas, Portugal). In CASCALHEIRA, J. GONÇALVES, C. (eds.) - Actas das IV Jornadas de Jovens em Investigação Arqueológica - JIA 2011, Vol. I (Faro, 11 a 14 de Maio de 2011).. Faro (Promontória Monográfica 16): 251-258.

NABAIS, M. - ZILHÃO, J. (2019) - The consumption of tortoise among Last Interglacial Iberian Neanderthals. Quaternary Science Reviews, 217: 225-246. DOI: https://doi.org/10.1016/j. quascirev.2019.03.024

NOLI, D. - AVERY, G. (1988) - Protein Poisoning and Coastal Subsistence. Journal of Archaeological Science, 15: 395-401.

PELLETIER, M. - DESCLAUX, E. - MALLYE, J. B. - CRÉGUT-BONNOURE, E. (2020) - Identifying the accidental-natural mortality of leporids in the archaeological record: insights from a taphonomical analysis of a pitfall without evidence of human presence. Journal of Quaternary Science, 35: 677-694. DOI: https://doi.org/10.1002/jqs.3203

PELLETIER, M. - ROYER, A. - HOLLIDAY, T.W. - MAUREILLE, B. (2015) - Lièvre et lapin à Regourdou (Montignac-sur-Vézère, Dordogne, France): Études paléontologique et taphonomique de deux accumulations osseuses d`origine naturelle. Paléo, 26: 161-183. DOI: https://doi.org/10.4000/paleo.3029

PICKERING, T. (2002) - Reconsideration of criteria for differentiating faunal assemblages accumulated by hyenas and hominids. International Journal of Osteoarchaeology, 12:127-141.

PRÉVOST, M. - GROMAN-YAROSLAVSKI, I. - CRATER GERSHTEIN, K. M. - TEJERO, J.M. - ZAIDNER, Y. (2021) - Early evidence for symbolic behavior in the Levantine Middle Paleolithic: A 120 ka old engraved aurochs bone shaft from the open-air site of Nesher Ramla, Israel. Quternary International. DOI: https://doi.org/10.1016/j.quaint.2021.01.002

RENDU, W. (2010) - Hunting behaviour and Neanderthal adaptability in the Late Pleistocene site of Pech-de-l'Azé I. Journal of Archaeological Science, 37: 1798-1810.

RODRÍGUEZ-HIDALGO, A. - SANZ, M. - DAURA, J. a - SÁNCHEZ-MARCO, A. (2020) - Taphonomic criteria for identifying Iberian lynx dens in Quaternary deposits. Scientific Reports, 10: 7225.
RUSSON, A. - COMPOST, A. - KUNCORO, P. - FERISA, A. (2014) - Orangutan fish eating, primate aquatic fauna eating, and their implications for the origins of ancestral hominin fish eating. Journal of Human Evolution, 77: 50-63.

SALADIÉ, P. - RODRÍGUEZ-HIDALGO, A. - DÍEZ, C. - MARTíN-RODRÍGUEZ, P. - CARBONELL, E. (2013) - Range of bone modifications by human chewing. Journal of Archaeological Science, 40: 380-397.

SALAZAR-GARCÍA, D. - POWER, R. A. - SANCHIS SERRA, A. A. VILLAVERDE, V. - WALKER, M. - HENRY, A. (2013) - Neanderthal diets in central and southeastern Mediterranean Iberia. Quaternary International, 318: 3-18. DOI: https://doi. org/10.1016/j.quaint.2013.06.007

SANCHIS, A. - REAL, C. - MORALES, J. - PÉREZ RIPOLL, M. TORMO, C. - CARRIÓN, Y. - PÉREZ, G. - RIBERA, A. - BOLUFER, J. - VILLAVERDE, V. (2014) - Towards the identification of a new taphonomic agent: An analysis of bone accumulations obtained from modern Egyptian vulture (Neophron percnopterus) nests. Quaternary International, 330: 136-149.

SCOTT, K. (1980) - Two hunting episodes of Middle Palaeolithic age at La Cotte de Saint-Brelade, Jersey (Channel Islands). World Archaeology, 12: 137-152.

SCOTT, K. (1986) - The large mammal fauna. In CALLOW, P. CORNFORD, J. (eds.) - La Cotte de St Brelade 1961-1978 excavations by C.B.M. Mcburney. Norwich: 109-139.

SELVAGGIO, M. (1998a) - Evidence for a three-stage sequence of hominid and carnivore involvement with long bones at FLK Zinjanthropus, Olduvai Gorge, Tanzania. Journal of Archaeological Science, 28: 465-470.

SELVAGGIO, M. (1998b) - Concerning the three stage model of carcass processing at FLK Zinjanthropus: A reply to Capaldo. Journal of Human Evolution, 35: 313-315.

SIEGFRIED, W. - HOCKEY, P. (1985) - Exploitation and Conservation of Brown Mussel Stocks by Coastal people of Transkei. Environmental Conservation, 12: 303-307.

SMITH, G. (2015) - Neanderthal megafaunal exploitation in Western Europe and its dietary implications: A contextual reassessment of La Cotte de St Brelade (Jersey). Journal of Human Evolution, 78: 181-201.

SORENSEN, A. - CLAUD, E. - SORESSI, M. (2018) - Neandertal fire-making technology inferred from microwear analysis. Scientific Reports, 8: 10065.

SPEED, E. (1969) - Prehistoric Shell Collectors. South African Archaeological Bulletin, 24: 193-196.

STANFORD, C. (1999) - The Hunting Apes: Meat eating and the origins of human behaviour. Princeton.

STINER, M. (1994) - Honor Among Thieves: A zooarchaeological study of Neandertal ecology. Princeton.

STINER, M. (2001) - Thirty years of the "Broad Spectrum Revolution" and Paleolithic demography. Proceedings of the National Academy of Sciences, 98: 6993-6996.

STINER, M. (2002) - Carnivory, coevolution and the geographical spread of the genus Homo. Journal of Archaeological Research 10: 1-63.

STINER, M. (2005) - The Faunas of the Hayonim Cave, Israel. A 20.000-Year Record of Paleolithic Diet, Demography and Society. Cambridge.

STINER, M. - KUHN, S. (2006) - Changes in the 'Connectedness' and Resilience of Paleolithic Societies in Mediterranean Ecosystems. Human Ecology, 34: 693-712. 
STINER, M. - MUNRO, N. (2002) - Approaches to prehistoric diet breadth, demography and prey ranking systems in time and space. Journal of Archaeological Method and Theory, 9: 181-214.

STINER, M. - MUNRO, N. (2011) - On the evolution of diet and landscape during the Upper Paleolithic through Mesolithic at Franchti Cave (Peloponnese, Greece). Journal of Human Evolution, 60: 618-636.

STINER, M. - MUNRO, N. - SUROVELL, T. - TCHERNOV, E. - BAR-YOSEF, O. (1999) - Paleolithic population growth pulses evidenced by small animal exploitation. Science, 283: 190-194.

STINER, M. - MUNRO, N. - SUROVELL, T. (2000) - The tortoise and the hare: small-game use, the broad-spectrum revolution, and Paleolithic demography. Current Anthropology, 41: 39-73.

STINER, M. - MUNRO, M. - STARKOVICH, B. (2012) - Material input rates and dietary breadth during the Upper Paleolithic through Mesolithic at Franchti and Klissoura 1 Caves (Peloponnese, Greece). Quaternary International, 275: 30-42.

STINER, M. - MUNRO, N. D. - SANZ, M. (2012) - Carcass damage and digested bone from mountain lion (Felis concolor): implications for carcass persistence on landscapes as function of prey age. Journal of Archaeological Science, 39: 896-907.

STOPP, M. (1997) - Early Human Adaptation in the Northern Hemisphere and the Implications of Taphonomy (BAR Series 669). Oxford.

STRINGER, C. - FINLAYSON, J. - BARTON, R. - FERNÁNDEZ-JALVO, Y. - CÁCERES, I. - SABIN, R. - RHODES, E. - CURRANT, A. RODRIGUEZ-VIDAL, J. - GILES-PACHECO, F. - RIQUELME-CANTAL, J. (2008) - Neanderthal exploitation of marine mammals in Gibraltar. Proceedings of the National Academy of Sciences, 105: 14319-14324.

THACKERAY, J. (1988) - Molluscan Fauna From Klasies River, South Africa. South African Archaeological Bulletin, 43: 27-32.

VANHAEREN, M. - ERRICO, F. - STRINGER, C. - JAMES, S. - TODD, J. - MIENIS, H. (2006) - Middle Paleolithic Shell Beads in Israel and Algeria. Science, 312: 1785-1788.

VILLA, P. (1990) - Torralba and Aridos: elephant exploitation in Middle Pleistocene Spain. Journal of Human Evolution, 19: 299-309.

VILLA, P. - ROEBROEKS, W. (2014) - Neanderthal Demise: an archaeological analysis of the Modern Human superiority complex. PLoS ONE, 9: e96424.

VILLA, P. - SOTO, E. - SANTONJA, M. - PÉREZ-GONZÁLEZ, A. MORA, R. - PARCERISAS, J. - SESÉ, C. (2005) - New data from Ambrona: closing the hunting versus scavenging debate. Quaternary International, 126-128: 223-250.

VOLMAN, T. (1978) - Early Archaeological Evidence for Shellfish Collecting. Science, 201: 911-913.

WARD, S. - GALE, R. - CARRUTHERS, W. (2012) - Late Pleistocene vegetation reconstruction at Gorham's Cave... In BARTON R. N. E. - STRINGER, C. B. - FINLAYSON, C. (eds.) - Neanderthals in Context. A Report of the 1995-1998 Excavations at Gorham's Cave and Vanguard Caves, Gibraltar. Oxford: 89-101.
WEYRICH, L. - DUCHENE, S. - SOUBRIER, J. - ARRIOLA, L. LLAMAS, B. - BREEN, J. - MORRIS, A. - ALT, K. - CARAMELLI, D.- DRESELY, V. - FARRELL, M. - FARRER, A. - FRANCKEN, M. - GULLY, N. - HAAK, W. - HARDY, K. - HARVATI, K. - HELD, P. - HOLMES, E. - KAIDONIS, J. - LALUEZA-FOX, C. - DE LA RASILLA, M. - ROSAS, A. - SEMAL, P. - SOLTYSIAK, A. TOWNSEND, G. - USAI, D. - WAHL, J. - HUSON, D. - DOBNEY, K. - COOPER, A. (2017) - Neanderthal behaviour, diet, and disease inferred from ancient DNA in dental calculus. Nature, 544: 357-361.

WIDMER, R., 1989. Archaeological Research Strategies in the Investigation of Shell-Bearing Sites, a Florida Perspective. Paper delivered at the Annual Meeting of the Society for American Archaeology, Atlanta.

WILL, M. - PARKINGTON, J. - KANDEL, A. - CONRAD, N. (2013) - Coastal adaptations and the Middle Stone Age lithic assemblages from Hoedjiespunt 1 in the Western Cape, South Africa. Journal of Human Evolution, 64: 518-537.

WIBING, C. - ROUGIER, H. - CREVECOEUR, I. - GERMONPRÉ, M. - NAITO, Y. - SEMAL, P. - BOCHERENS, H. (2016) - Isotopic evidence for dietary ecology of late Neandertals in North-Western Europe. Quaternary International, 411, Part A: 327-345.

YRAVEDRA, J. - RUBIO-JARA, S. - PANERA, J. - URIBELARREA, D. - PÉREZ-GONZÁLEZ, A. (2012) - Elephants and subsistence. Evidence of the human exploitation of extremely large mammal bones from the Middle Palaeolothic site of PRERESA (Madrid, Spain). Journal of Archaeological Science, 39: 1063-1071.

ZEDER, M. (2012) - The Broad Spectrum Revolution at 40: Resource diversity, intensification, and an alternative to optimal foraging explanations. Journal of Anthropological Archaeology, 31: 241-264.

ZILHÃO, J. - ANGELUCCI, D. - BADAL-GARCÍA, E. - ERRICO, F. DANIEL, F. - FAYET, L. - DOUKA, K. - HIGHAM, T. - MARTÍNEZ-SÁNCHEZ, M. - MONTES-BERNÁRDEZ, R. - MURCIA-MASCARÓS, S. - PÉREZ-SIRVENT, C. - ROLDÁN-GARCÍA, C. - VANHAEREN, M. - VILLAVERDE, V. - WOOD, R. - ZAPATA, J. (2010) - Symbolic use of marine shells and mineral pigments by Iberian Neanderthals. Proceedings of the National Academy of Science of the United States of America, 107: 1023-1028.

ZILHÃO, J. - ANGELUCCI, D. - ARAÚJO, M. - ARNOLD, L. - BADAL, E. - CALLAPEZ, P. - CARDOSO, J. - D'ERRICO, F. - DAURA, J. DEMURO, M. - DESCHAMPS, M. - DUPONT, C. - GABRIEL, S. - HOFFMANN, D. - LEGOINHA, P. - MATIAS, H. - SOARES, A. M. - NABAIS, M. - PORTELA, P. - RODRIGUES, F. - SOUTO, P. (2020) - Last Interglacial Iberian Neandertals as Fisher-Hunter-Gatherers. Science, 367: eaaz7943.

ZILHÃO, J. - BANKS, W. - D'ERRICO, F. - GIOIA, P. (2015) - Analysis of Site Formation and Assemblage Integrity Does Not Support Attribution of the Uluzzian to Modern Humans at Grotta del Cavallo. PLoS ONE, 10: e0131181. 


\section{POLÍTICA EDITORIAL}

A Ophiussa - Revista do Centro de Arqueologia da Universidade de Lisboa foi iniciada sob a direcção de Victor S. Gonçalves em 1996, tendo sido editado o volume 0. O volume 1 (2017) é uma edição impressa e digital da UNIARQ - Centro de Arqueologia da Universidade de Lisboa.

O principal objectivo desta revista é a publicação e divulgação de trabalhos com manifesto interesse, qualidade e rigor científico sobre temas de Pré-História e Arqueologia, sobretudo do território europeu e da bacia do Mediterrâneo.

A Ophiussa - Revista do Centro de Arqueologia da Universidade de Lisboa publicará um volume anual. A partir de 2018, os artigos submetidos serão sujeitos a um processo de avaliação por parte de revisores externos (peer review). O período de submissão de trabalhos decorrerá sempre no primeiro trimestre e a edição ocorrerá no último trimestre de cada ano.

A revista divide-se em duas secções: artigos científicos e recensões bibliográficas. Excepcionalmente poderão ser aceites textos de carácter introdutório, no âmbito de homenagens ou divulgações específicas, que não serão submetidos à avaliação por pares. Isentas desta avaliação estão também as recensões bibliográficas.

Todas as submissões serão avaliadas, em primeira instância, pela Coordenação Editorial, no que respeita ao seu conteúdo formal e à sua adequação face à política editorial e às normas de edição da revista. Os trabalhos que cumprirem estes requisitos serão posteriormente submetidos a um processo de avaliação por pares cega / blind peer review (mínimo de dois revisores). O Conselho Científico, constituído pela direcção da UNIARQ e por investigadores externos, acompanhará o processo de edição.

Esta etapa será concretizada por investigadores externos qualificados, sendo os respectivos pareceres entregues num período não superior a três meses. Os revisores procederão à avaliação de forma objectiva, tendo em vista a qualidade do conteúdo da revista; as suas críticas, sugestões e comentários serão, na medida do possível, construtivos, respeitando as capacidades intelectuais do(s) autor(es). Após a recepção dos pareceres, o(s) autor(es) tem um prazo máximo de um mês para proceder às alterações oportunas e reenviar o trabalho.

A aceitação ou recusa de artigos terá como únicos factores de ponderação a sua originalidade e qualidade científica. O processo de revisão é confidencial, estando assegurado o anonimato dos avaliadores e dos autores dos trabalhos, neste último caso até à data da sua publicação.

Os trabalhos só serão aceites para publicação a partir do momento em que se conclua o processo da revisão por pares. Os textos que não forem aceites serão devolvidos aos seus autores. O conteúdo dos trabalhos é da inteira respon- sabilidade do(s) autor(es) e não expressa a posição ou opinião do Conselho Científico ou da Coordenação Editorial. A Revista Ophiussa segue as orientações estabelecidas pelo Commitee on Publication Ethics (COPE, Comité de Ética em Publicações): https://publicationethics.org/.

O processo editorial decorrerá de forma objectiva, imparcial e anónima. Erros ou problemas detetados após a publicação serão investigados e, se comprovados, haverá lugar à publicação de correções, retratações e/ou respostas. As colaborações submetidas para publicação devem ser inéditas. As propostas de artigo não podem incluir qualquer problema de falsificação ou de plágio. Para efeito de detecção de plágio será utilizada a plataforma URKUNDU (https:// www.urkund.com/pt-br/).

As ilustrações que não sejam do(s) autor(es) devem indicar a sua procedência. O Conselho Científico e a Coordenação Editorial assumem que os autores solicitaram e receberam autorização para a reprodução dessas ilustrações, e, como tal, rejeitam a responsabilidade do uso não autorizado das ilustrações e das consequências legais por infracção de direitos de propriedade intelectual.

É assumido que todos os Autores fizeram uma contribuição relevante para a pesquisa reportada e concordam com o manuscrito submetido. Os Autores devem declarar de forma clara eventuais conflitos de interesse. As colaborações submetidas que, direta ou indiretamente, tiveram o apoio económico de terceiros, devem claramente declarar essas fontes de financiamento.

Os textos propostos para publicação devem ser inéditos e não deverão ter sido submetidos a qualquer outra revista ou edição electrónica. Aceitam-se trabalhos redigidos em português, inglês, espanhol, italiano e francês.

Esta edição disponibiliza de imediato e gratuitamente a totalidade dos seus conteúdos, em acesso aberto, de forma a promover, globalmente, a circulação e intercâmbio dos resultados da investigação científica e do conhecimento.

A publicação de textos na Ophiussa - Revista do Centro de Arqueologia da Universidade de Lisboa não implica o pagamento de qualquer taxa nem dá direito a qualquer remuneração económica.

Esta publicação dispõe de uma versão impressa, a preto e branco, com uma tiragem limitada, que será distribuída gratuitamente pelas bibliotecas e instituições mais relevantes internacionalmente, e intercambiada com publicações periódicas da mesma especialidade, que serão integradas na Biblioteca da Faculdade de Letras da Universidade de Lisboa. Conta, paralelamente, com uma versão digital, a cores, disponibilizada no endereço www.ophiussa.letras.ulisboa.pt, onde se pode consultar a totalidade da edição.

Para mais informações: ophiussa@letras.ulisboa.pt 


\section{EDITORIAL POLICY}

Ophiussa - Revista do Centro de Arqueologia da Universidade de Lisboa started in 1996, with the edition of volume 0 . From 2017, this journal is a printed and digital edition of UNIARQ - Centro de Arqueologia da Universidade de Lisboa.

The main objective of this journal is the publication and dissemination of papers of interest, quality and scientific rigor concerning Prehistory and Archeology, mostly from Europe and the Mediterranean basin.

Ophiussa - Revista do Centro de Arqueologia da Universidade de Lisboa will publish an annual volume. From 2018, submitted articles will be subject to a peer-review evaluation process. The submission period will always occur in the first quarter of each year and the edition will occur in the last quarter.

The journal is divided into two sections: scientific articles and bibliographic reviews. Exceptionally, texts of an introductory nature may be accepted, in the context of specific tributes or divulgations, which will not be submitted to peer-review evaluation. Exemptions from this evaluation are also the bibliographic reviews.

All submissions will be considered, in the first instance, by the Editorial Board, regarding its formal content and adequacy in face of the editorial policy and the journal's editing standards. Papers that meet these requirements will subsequently be submitted to a blind peerreview process (minimum of two reviewers). The Scientific Council, constituted by the directors of UNIARQ and external researchers, will follow the editing process.

This stage will be carried out by qualified external researchers, and their feedback will be delivered within a period of no more than two months. The reviewers will carry out the evaluation in an objective manner, in view of the quality and content of the journal; their criticisms, suggestions and comments will be, as far as possible, constructive, respecting the intellectual abilities of the author(s). After receiving the feedback, the author(s) has a maximum period of one month to make the necessary changes and resubmit the work.

Acceptance or refusal of articles will have as sole factors of consideration their originality and scientific quality. The review process is confidential, with the anonymity of the evaluators and authors of the works being ensured, in the latter case up to the date of its publication.

Papers will only be accepted for publication as soon as the peer review process is completed. Texts that are not accepted will be returned to their authors. The content of the works is entirely the responsibility of the author(s) and does not express the position or opinion of the Scientific Council or Editorial Board. The Journal Ophiussa follows the guidelines established by the Commitee on Publication Ethics (COPE, the Ethics Committee Publications): https:// publicationethics.org/
The editorial process will be conducted objectively, impartially and anonymously. Errors or problems detected after publication will be investigated and, if proven, corrections, retractions and / or responses will be published. Contributions submitted for publication must be unpublished. Article submissions can not include any problem of forgery or plagiarism. In order to detect plagiarism, the URKUNDU platform will be used.

Illustrations that are not from the author(s) must indicate their origin. The Scientific Council and Editorial Board assume that the authors have requested and received permission to reproduce these illustrations and, as such, reject the responsibility for the unauthorized use of the illustrations and legal consequences for infringement of intellectual property rights.

It is assumed that all Authors have made a relevant contribution to the reported research and agree with the manuscript submitted. Authors must clearly state any conflicts of interest. Collaborations submitted that directly or indirectly had the financial support of third parties must clearly state these sources of funding.

Texts proposed for publication must be unpublished and should not have been submitted to any other journal or electronic edition. Works written in Portuguese, English, Spanish, Italian and French are accepted.

The publication of texts in Ophiussa - Revista do Centro de Arqueologia da Universidade de Lisboa does not imply the payment of any fee nor does it entitle to any economic remuneration.

This edition immediately and freely provides all of its content, in open access, in order to promote global circulation and exchange of scientific research and knowledge. This publication has a limited printed edition in black and white, which will be distributed free of charge by the most relevant international libraries and institutions, and exchanged with periodicals of the same specialty, which will be integrated in the Library of Faculdade de Letras of Universidade de Lisboa. It also has a digital version, in color, available at address http://ophiussa.letras.ulisboa.pt, where one can consult the entire edition.

For more information contact: ophiussa@letras.ulisboa.pt 
REVISTA DO CENTRO DE ARQUEOLOGIA DA UNIVERSIDADE DE LISBOA

ÍNDICE

O tecno-complexo Acheulense em Portugal:

contribuição para um balanço dos conhecimentos

CARLOS FERREIRA, JOÃO PEDRO CUNHA-RIBEIRO, EDUARDO MÉNDEZ-QUINTAS

Brief overview of zooarchaeological research within the framework

of Middle Palaeolithic subsistence theories

MARIANA NABAIS

A distribuição espacial dos materiais líticos da UE003 do Rodo:

testemunho de reocupações do sítio ao longo do Tardiglaciar?

CRISTINA GAMEIRO, THIERRY AUBRY, BÁRBARA COSTA, SÉRGIO GOMES,

YANN LE JEUNE, CARMEN MANZANO, MAURIZIO ZAMBALDI

O sítio do Neolítico Antigo de Montum de Baixo (Melides - Alentejo Litoral)

63

JOAQUINA SOARES, CARLOS TAVARES DA SILVA, SUSANA DUARTE

A economia alimentar em Chibanes (Setúbal) - horizonte campaniforme

JOÃO LUÍS CARDOSO, CARLOS TAVARES DA SILVA, JOAQUINA SOARES, FILIPE MARTINS

Luto en la cara: ablaciones de duelo en el Mediterráneo Ancestral

ÁLVARO GÓMEZ PEÑA, JOSÉ LUIS ESCACENA CARRASCO

Dois conjuntos anfóricos do Castelo de São Jorge (Lisboa):

Largo de Santa Cruz do Castelo e Pátio José Pedreira

VICTOR FILIPE

A face romana de Santa Olaia (Figueira da Foz, Portugal) -

uma leitura possível a partir da cultura material

RICARDO COSTEIRA DA SILVA, SARA OLIVEIRA ALMEIDA, ISABEL PEREIRA

Cerâmica estampada britânica em Portugal (1780-1920).

Identidade, domesticidade e relações

TÂNIA CASIMIRO, INÊS CASTRO, TIAGO SILVA

Recensões bibliográficas

(TEXTOS: JOÃO LUÍS CARDOSO, ANA CATARINA SOUSA, VICTOR S. GONÇALVES,

FRANCISCO B. GOMES, PEDRO ALBUQUERQUE, LEYRE MORGADO-RONCAL)

Política editorial 